\title{
Involvement of Probiotics and Postbiotics in the Immune System Modulation
}

\author{
Neslihan Yeşilyurt ${ }^{1}$, Birsen Yılmaz ${ }^{1,2} \mathbb{D}$, Duygu Ağagündüz ${ }^{1, *(\mathbb{D})}$ and Raffaele Capasso ${ }^{3, *(D)}$ \\ 1 Department of Nutrition and Dietetics, Faculty of Health Sciences, Gazi University, Emek, \\ Ankara 06490, Turkey; yesilyurtnesli@gmail.com (N.Y.); dytbirsen@gmail.com (B.Y.) \\ 2 Department of Nutrition and Dietetics, Faculty of Health Sciences, Çukurova University, Sarıçam, \\ Adana 01330, Turkey \\ 3 Department of Agricultural Sciences, University of Naples Federico II, 80055 Portici, NA, Italy \\ * Correspondence: duyguturkozu@gazi.edu.tr (D.A.); rafcapas@unina.it (R.C.)
}

Citation: Yeşilyurt, N.; Yılmaz, B.;

Ağagündüz, D.; Capasso, R.

Involvement of Probiotics and

Postbiotics in the Immune System

Modulation. Biologics 2021, 1, 89-110.

https://doi.org/10.3390/

biologics1020006

Academic Editor:

Vasso Apostolopoulos

Received: 30 May 2021

Accepted: 2 July 2021

Published: 6 July 2021

Publisher's Note: MDPI stays neutral with regard to jurisdictional claims in published maps and institutional affiliations.

Copyright: (c) 2021 by the authors. Licensee MDPI, Basel, Switzerland. This article is an open access article distributed under the terms and conditions of the Creative Commons Attribution (CC BY) license (https:// creativecommons.org/licenses/by/ $4.0 /)$.

\begin{abstract}
Intestinal microbiota interacts with other systems, especially the immune system, which is responsible for protecting the body by recognizing "stranger" (pathogen associated molecular patterns-PAMPs) and "danger" (damage-associated molecular patterns-DAMPs) molecular motifs. In this manner, it plays an important role in the pathogenesis of various diseases and health. Despite the use of probiotics that modulate the intestinal microbiota in providing health benefits and in the treatment of diseases, there are some possible concerns about the possibility of developing adverse effects, especially in people with suppressed immune systems. Since probiotics provide health benefits with bioactive compounds, studies are carried out on the use of products containing non-living probiotic microorganisms (paraprobiotics) and/or their metabolites (postbiotics) instead of probiotic products. It is even reported that these microbial compounds have more immunomodulatory activities than living microorganisms via some possible mechanism and eliminates some disadvantages of probiotics. Considering the increasing use of functional foods in health and disease, further studies are needed with respect to the benefits and advantages of parabiotic and/or postbiotic use in the food and pharmaceutical industry as well as immune system modulation. Although probiotics have been extensive studied for a long time, it seems that postbiotics are promising tools for future research and applications according to the recent literature. This review aimed to evaluate the interaction of probiotics and postbiotics with the immune systems and also their advantages and disadvantages in the area of food-pharmaceutical industry and immune system modulation.
\end{abstract}

Keywords: probiotics; parabiotics; postbiotics; immune system

\section{Introduction}

Immune system modulation is one of the hot topics of today. The main function of the immune system is to defend us against pathogens by recognizing "stranger" (pathogen associated molecular patterns-PAMPs) and "danger" (damage-associated molecular patternsDAMPs) molecular motifs according to the danger theory. In this way, it plays an important role in the pathogenesis of various diseases and health [1-3].

The immune system basically performs this defense function by integration of various host barriers and cellular and humoral agents such as immune system mechanisms [4]. It mainly performs this defense function by two mechanisms: the innate and adaptive immune system [2]. Physical barriers, which is served as the skin, mucous membranes, and endothelia throughout the body that prevent the entry of microbes into the host and reaching potential sites of infection, comprises the innate immunity [5]. Moreover, the physical barrier, which is the first line of defense, is composed of microorganisms that are hosted in our body and colonized outside the epithelial cells of the skin and gastrointestinal system $[4,6]$. These microorganism communities are defined as microbiota. The genetic material of the microorganisms that make up the microbiota is called the 
microbiome [7]. Current literature suggest that gut microbiome and/or a new organ system are especially commensal mainly due to the microorganisms' specific biochemical interaction and systemic integration with their hosts [8].

Gut microbiota, in other words intestinal microbiota which is the intestinal flora of the human body, has a vital role in human health, especially in the development of the host immune system and the regulation of metabolic events [9]. Given the health effects of intestinal microbiota, there is an increasing interest in probiotics, prebiotics, and synbiotics, which are closely related to the microbiota for health promotion [10]. Probiotics are defined by the International Scientific Association for Probiotic and Prebiotic (ISAPP) as "living microorganisms that create health benefits in the host when taken in sufficient amounts" and prebiotics as "inanimate food ingredients that support health in the host through microbiota modulation" [11,12]. The definition of synbiotics was updated with the consensus published in 2020 as "a mixture containing live microorganisms and substrate(s) selectively used by host microorganisms, beneficially affecting to the host" [13].

Although they have beneficial effects on health, the World Health Organization (WHO) and The Food and Agriculture Organization (FAO) reported that probiotics may have some side effects and safety issues may arise due to the use of living microbial cells [14]. There is evidence that the use of forms or metabolites of living microorganisms inactivated by various methods can eliminate safety problems and reduce the risk of infection in individuals with increased intestinal permeability and weak immune systems [15]. While terms such as paraprobiotics, parapsychobiotics, ghost probiotics, metabiotics, and postbiotics are used to refer to these probioactive compounds that do not fit the definitions of probiotics, prebiotics, or synbiotics, ISAPP proposed the use of the term "postbiotic" in the consensus of 2021 [16]. Literature investigating the efficacy of postbiotics and paraprobiotics report their potential, such as probiotics, in demonstrating various health benefits in the host and those involved in immune system modulation [17]. Moreover, postbiotics have mainly been associated with immunomodulatory activities by playing a role in maintaining the integrity of the intestinal mucosal barrier and antagonizing pathogens with antimicrobial compounds by stimulating the innate and adaptive immune system [18].That is why one of the emerging topic is the role of some metabolites of probiotics such as postbiotics or their different (non-living) forms, such as parabiotics, in the immune system modulation. This review aimed to focus on probiotics, parabiotics, and postbiotics and their involvement in the immune system.

\section{Immune System}

Humans live with many microorganisms. One of the two main functions (i.e., recognizing DAMPs and PAMPs) of the immune system is to defend the body against pathogens by separating body cells and pathogenic microorganisms [1,2]. It basically performs this defense task with various mechanisms. First, pathogens encounter physical barriers and the innate immune system activates to protect the body. If pathogens penetrate them, the adaptive immune system is activated as the secondary line of defense [4].

Physical barriers, the body's first line of defense against pathogens, consist of epithelial layers in the skin, gastrointestinal system, respiratory system, and urogenital tract [19]. The pathogens are captured by mucus secreted from these epithelial layers and excreted by the cilia found there [20]. Pathogens that can penetrate the mucous layer are phagocytosed by binding to antimicrobial molecules such as $\alpha$ and $\beta$ defensins, cathelicidin secreted from the skin, respiratory and gastrointestinal tracts, or degraded by enzymes such as RNAse, DNAse, and lysozyme [21]. Acidic $\mathrm{pH}$ of the skin, vagina, and stomach may also prevent pathogens from colonizing in these epithelial layers [22]. It fights pathogens that go beyond these chemical barriers, competing for microbiota nutrients that act as the body's biological barrier, stimulating $\mathrm{T}$ cells and antibody synthesis, or secreting antimicrobial molecules (e.g., short-chain fatty acids-SCFA) [23]. However, when the immune system functions in the body are impaired, microorganisms that make up the microbiota may also show pathogenic features [24]. 
When pathogens cross physical barriers and the innate immune system, an inflammatory response is generated by the second line of defense and components [25]. For neutrophils, basophils, dendritic cells, eosinophils, Kupffer cells, tissue macrophages such as alveolar macrophages, and phagocytic cells called monocytes in the blood, the Fc (constant and crystallized part of Ig) part of IgG and IgA on their surface bind to the pathogen with special receptors they carry for various factors involved in the complement system and inflammation and they also bind and clear to pathogens with the proteins in their granules by phagocytosis [26]. For example, components such as bacterial lipopolysaccharides (LPS) found in the outer membrane of pathogenic bacteria are recognized by Toll-like-4 receptors (TLR4) on the surface of monocytes and macrophages. TLR4 and other TLRs such as TLR2 and TLR9 are involved in the formation of inflammation by stimulating the activation of genes responsible for cytokine and antimicrobial molecule production in the nucleus [27]. TLRs are involved in the formation of inflammation by stimulating the activation of genes responsible for cytokine and antimicrobial molecule production in the nucleus [27]. Natural killer cells (polymorphonuclear cell-NK) are non-phagocytic granular lymphocytes responsible for killing infected body cells [20].

Some substances secreted by pathogens cause chemotaxis in phagocytic cells [28]. Monocyte-macrophages and other cells secrete cytokines such as interleukin-1 (IL-1), tumor necrosis factor- $\alpha$ (TNF- $\alpha$ ), and interferons (IFN), causing fever and thus increasing the severity of inflammation [29]. If the innate immune system against pathogens is inadequate, the adaptive immune system creates pathogen-specific immune responses with immunological defense mechanisms and the severity of the response and intensity increases after the first encounter with the pathogen thanks to immunological memory [30,31].

B lymphocytes that develop from pluripotent hematopoietic stem cells in the bone marrow produce antigen-specific immunoglobulins (IgM, IgD, IgG, IgA, and $\operatorname{IgE}$ ) and enable the formation of a humoral immune response by allowing the recognition of antigens by other cells by binding Igs' to the antigen [32]. Macrophages are activated by Th1 cells from the CD4+ T cell (Th) group [33]. Th1 also releases cytokines such as interleukin-2 (IL-2) and interferon-gamma (INF- $\gamma$ ), resulting in cellular immunity that protects against intracellular infectious agents such as viruses, mycobacteria, and fungi [34]. Th2, on the other hand, stimulates B lymphocytes, which are the most essential elements of humoral immunity, which enable a response to extracellular pathogens by producing cytokines such as IL-4, IL-10, and IL-6 that stimulate immunoglobulin production [35]. The task of Th17 cells is to stimulate tissue inflammation by producing IL-17 in cases where Th1 and Th2 mediated responses are insufficient. Research has reported that Th17-mediated response plays a role in the pathogenesis of autoimmune diseases such as rheumatoid arthritis, multiple sclerosis, inflammatory bowel disease, psoriasis, and asthma [36]. Other members of the Th group, T regulator cells (Foxp3+ T regulator-Treg) are defined as $\mathrm{T}$ cells responsible for suppressing potentially deleterious activities of $\mathrm{T}$ and $\mathrm{B}$ cells [37]. Treg cells prevent the development of autoimmunity by controlling Th1 or Th2 responses via the immunosuppressive cytokine TGF- $\beta$ [38].

\section{The Role of Toll-Like Receptors (TLRs) in Intestinal Epithelial Cells}

The TLR consists of an IL-1 receptor-like cytoplasmic region (Toll/IL-1 receptor-TIR) and an extracellular region containing a leucine-rich LRR that enables the recognition of pathogens [39,40]. TLRs are a member of the PRR family, such as the nucleotide-binding oligomerization domain-like receptors or NOD-like receptors (NLRs) and C-type lectin receptors. PRRs are activated by specific PAMP containing various microorganism components such as peptidoglycan, LPS, flagellin, bacterial RNA/DNA, and fungal cell wall glucans [41,42]. There are 11 TLRs identified on cell surfaces, mainly monocyte/macrophage and B lymphocytes [43]. Almost all TLRs are produced in the intestines, which act as a physical barrier, especially TLR3, TLR1, TLR2, TLR3, TLR4, TLR5, and TLR9 in small intestinal epithelial cells and TLR5 in the colon [44-46]. Myeloid differentiation factor 88 (MyD88) and TIR-related protein (TIRAP), which play a role in the secretion of proinflam- 
matory cytokines (TNF- $\alpha$, IL- $\beta$, IL-6, IL-8, and IL-10) in TLR signaling pathways other than TLR3, TIR region IFN-beta inducing adapter protein (TRIF) and TRIF-associated adapter molecule (TRAM), which stimulate the secretion of interferons (INF- $\alpha$, INF- $\beta$, and INF- $\gamma$ ), are involved in the generation of the inflammatory response [47].

TLRs allow microbial membrane components such as lipid, lipoprotein, protein to be recognized by binding to PAMPs found in microorganisms and plays a role in the formation of the immune response by stimulating the secretion of inflammatory mediators (Table 1) [47,48]. Antimicrobial molecules secreted by intestinal epithelial cells act by disrupting the cell wall structures of both pathogenic bacteria and the intestinal microbiota [49]. Antimicrobial molecules are secreted by the mechanism associated with pattern recognition receptor (PRR) and intestinal epithelial cells [41]. Activation of various signaling pathways required for mucosal barrier functions, antimicrobial molecules, mucin glycoproteins, and IgA production occurs through PRR-PAMP interaction [50]. In addition, TLRs activated by PAMP interact with MyD88 and TRIF pathways in the cell according to the localization of TLRs and prevents bacteria from adhering to epithelial cells [51]. TLRs are involved in the formation of the immune response, thus increasing the susceptibility to dysregulation, dysbiosis, and inflammation [52].

Table 1. Cells with TLRs, their ligands, and the cytokines they stimulate to be secreted.

\begin{tabular}{|c|c|c|c|c|}
\hline TLR & Cell in Which It Is Located & PAMP & $\begin{array}{c}\text { Cytokine with } \\
\text { Stimulated Secretion }\end{array}$ & References \\
\hline 1 & $\begin{array}{c}\text { Monocyte/macrophages } \\
\text { Dendritic Cells } \\
\text { B lymphocytes }\end{array}$ & Triacyl lipopeptides & IL-6, IL-10, TNF- $\alpha$ & [53] \\
\hline 2 & $\begin{array}{c}\text { Monocyte/macrophages } \\
\text { Dendritic Cells } \\
\text { Mast Cells }\end{array}$ & $\begin{array}{l}\text { Diacyl and triacyl } \\
\text { lipopeptides } \\
\text { Peptidoglycan } \\
\text { Lipoteichoic acid }\end{array}$ & $\begin{array}{l}\text { IL-6, TNF- } \alpha, \text { IL-1 } \beta, \\
\text { IL-10 }\end{array}$ & {$[54,55]$} \\
\hline 3 & $\begin{array}{l}\text { Dendritic Cells } \\
\text { B lymphocytes }\end{array}$ & Viral DNA & INF- $\gamma$ & [56] \\
\hline 4 & $\begin{array}{l}\text { Monocyte/macrophages } \\
\text { Dendritic Cells } \\
\text { Mast Cells } \\
\text { Intestinal epithelium }\end{array}$ & Lipopolysaccharide & IL-1 $\beta$, INF- $\gamma$ & [57] \\
\hline 5 & $\begin{array}{c}\text { Monocyte/macrophages } \\
\text { Dendritic Cells } \\
\text { Intestinal epithelium }\end{array}$ & Flagellin & IL-6, TNF- $\alpha$, IL-10 & [58] \\
\hline 6 & $\begin{array}{c}\text { Monocyte/macrophages } \\
\text { Mast Cells } \\
\text { B lymphocytes }\end{array}$ & $\begin{array}{l}\text { Diacyl lipopeptides } \\
\text { Lipoteichoic acid }\end{array}$ & IL-1 $\beta$ & {$[55,59]$} \\
\hline
\end{tabular}

PAMP: pathogen associated molecular pattern, IL-6: Interleukin-6, IL-10: Interleukin-10, TNF- $\alpha$ : Tumor necrosis factor- $\alpha$, IL-1 $\beta$ : Interleukin$1 \beta$, DNA: Deoxyribonucleic acid, INF- $\gamma$ : Interferon- $\gamma$.

\section{Microbiota and Immune System}

The human body maintains a symbiotic life with a microorganism as much as its own cell number (1:1 ratio) according to current literature [60]. These microorganisms, which were previously called the flora of the region they colonized in the body, are defined as microbiota and the genetic material of microbiota is defined as microbiome [7,9]. The close relationship of microbiota with health, especially the immune system, has started to be understood with the Human Microbiome Project (IMP), which was initiated in 2007 as a continuation of the Human Genome Project (IGP) and aims to examine the interaction of the microbiome with genetics, age, gender, nutrition, drugs, environmental factors, and consequently its effect on human health $[61,62]$.

Bacteria, fungi, viruses, and other microorganisms that make up the microbiota are mostly colonized in the intestine of the human body due to its large surface area and being rich in nutrient quantity diversity [63]. According to a microbiome theory, intestinal 
microbiota begins to develop in the prenatal (intrauterine) period and reaches the adult diversity at an average age of 2.5 years (In the intestinal microbiota, there are more than 10 phylum member bacteria including Proteobacteria, Verrucomicrobia, Actinobacteria, Fusobacteria, and Cyanobacteria and most of them belongs to Bacteroidetes and Firmicutes phyla.) and is influenced by many factors such as the mode of delivery; nutrition (Bifidobacterium phylum was found to be more dominant in the microbiota in the 20 following birth in infants born by normal birth and breastfed than in infants born by cesarean section and formula-fed); whether antibiotics are used or not (Antibiotic use in childhood have been associated with obesity, diabetes, inflammatory bowel disease, asthma, and allergies); and the geographic characteristics of the living environment [64-66]. On the other hand, there is not yet enough evidence whether the microbiome starts in the womb. There are two theories about the human microbiome formation process. Some scientists believed that the human fetal environment was sterile and babies were born sterile while others have stated intestinal microbiota begins to form in the intrauterine period $[67,68]$.

Intestinal microbiota is effective in the development of the immune system [69]. It is characterized by the under development of the immune system in infancy, increased sensitivity to pathogens, and the occurrence of allergies and infectious diseases, which are the leading causes of infant death [70,71]. A study in mice showed that the microbiota of pregnant mice induced antibody-mediated protective immunity in nursing newborn mice [72]. Breast milk, which contains all the nutrients required for the growth and development of the infant and bioactive compounds necessary for the modulation of their health, supports the development of the baby's immune system with a unique microbiota. The researchers noted that the microbiota composition of breast milk was composed of Staphylococcus, Streptococcus, Veillonella, Gemella, Enterococcus, Clostridia, Bifidobacterium, Lactobacillus, Propioni, Actinomyces, Corynebacterium, Pseudomonas, Sphingomonas, Serratia, Escherichia, Enterobacter, and Ralstonia, Bradyrhizobium ve Prevotella [73,74]. In a study examining the relationship between microbiota and immune system development, it has been shown that lymphoid tissue structure and impaired immune function are associated with deep bowel defects in germ-free (GF-sterile) mice [75]. However, in another study comparing immunological and epithelial barrier properties of preterm pigs and GF term pigs, researchers observed that GF term pigs developed less immunological mechanisms and epithelial barrier properties than term pigs and GF term pigs showed mild signs of inflammation in a sterile environment [76]. Indeed, it seems that there are still some important mechanisms and pathways to be clarified on this issue.

The intestinal microbiota, together with macrophage and dendritic cells of the innate immune system, $\mathrm{T}$ and $\mathrm{B}$ lymphocytes of the adaptive immune system (responsible for IgA production), and intestinal associated lymphoid tissue (GALT) are involved in the development of the immune response [77]. Bacteria forming the intestinal microbiota stimulates the production of TLR-MyD88 signal-related IL- $1 \beta$ and function in the formation of the Th1 response by inducing the formation of IL-17 from Th-17 cells. The polysaccharide A found in Bacteroides phylum bacteria and the butyrate SCFA produced by the bacteria forming the microbiota stimulate the immune system cells and release TGF- $\beta$ and IL- 10 . TGF- $\beta$ and IL-10 stimulate the production of Treg cells, preventing the formation of T lymphocyte response, and exhibits anti-inflammatory effects [78]. In addition, a study reported that butyrate can stimulate the conversion of monocytes to macrophages through histone deacetylase 3 (HDAC3) inhibition, thus enhancing antimicrobial host defense [79].

\section{Dysbiosis and Immune System}

The ratio of Bacteriodetes and Firmicutes phyla with the largest colony of bacteria, which are the dominant microorganisms of the intestinal microbiota, varies between 1:1 and 1:3 in healthy individuals $[80,81]$. This condition is called "eubiosis" and the condition in which the balance is disturbed is called "dysbiosis". It has been indicated that dysbiosis is associated with plenty of diseases, particularly rheumatoid arthritis, inflammatory bowel 
disease (IBD), cancer, irritable bowel syndrome (IBS), autism, liver disease, celiac, obesity, diabetes, and cardiovascular and respiratory diseases [82].

Intestinal microbiota and associated metabolites induce tissue-specific local immune responses because of increased intestinal lumen permeability and translocation to various organs via the circulatory system [83]. For example, in liver disease and obesity, increased Gram negative (G-) bacteria enter the circulation and are recognized by LPS sensing TLR4, which are found in cell walls, resulting in the formation of the inflammatory response by providing upregulation of various proinflammatory chemokines and adhesion molecules [84]. In one study, it was reported that the intra-tumor microbiota in pancreatic adenocarcinoma in mice and humans induced carcinogenesis by stimulating the induction of immune tolerance by suppressing the differentiation of monocytes through selective TLRs and T cell anergy [85].

In patients with celiac disease, gluten intolerance is associated with activation of gluten-specific CD4+ T cells in the lamina propria and the upregulation of IL-15, which is a proinflammatory cytokine [86]. The intestinal microbiota is involved in the maturation of dendritic cells and the macrophages in the small intestine and causes variation in the interactions of gliadin peptides with CD4+ T cells [87]. Pathogenic bacteria activate the innate immune system through the TLR. TLR4 and CD14 complexes recognize bacterial LPS and activates the innate immune system to release proinflammatory cytokines. Soluble CD14 is a serum marker that indicates increased activation of the immune system in untreated celiac patients and this marker indicates the role of dysbiosis in the pathogenesis of the celiac disease. In the case of dysbiosis, bacteria can also activate Th1, Th2, and Th17 mediated immune responses such as the upregulation of gliadin peptides [88].

IBD is a chronic, recurrent inflammatory GI disorder characterized by an increasing global prevalence involving Crohn's disease (CD) and ulcerative colitis (UC) $[89,90]$. Chronic inflammation of the mucosa developing with IBD impairs mucosal integrity by affecting tight junctions in intestinal epithelial cells, Zonula occludens-1 (ZO-1), and occluding transmembrane proteins. This results in the passage of pathogens across the mucosal barrier, further resulting in the increased severity of TLR-mediated inflammation [91]. Studies have reported that dysbiosis due to the decrease in Firmicutes and Bacteriodetes phylum and the increase in Proteobacteria and Fusobacterium phylum play a role in the pathogenesis of IBD [92-94]. IBS, on the other hand, is a chronic functional bowel disease of unknown etiology, which is clinically characterized by gastrointestinal system (GIS) symptoms without an organic pathology. There is a chronic inflammation condition in IBS that is not as apparent as IBD [95]. Literature shows that there is mast cell infiltration in the intestines and that the level of proinflammatory cytokines in the circulation increases [96]. It has been reported that TLR regulation is disrupted in IBS patients with an increase in TLR4 and TLR5 expression and a decrease in TLR7 and TLR8 expression [97].

Severe Acute Respiratory Syndrome-Coronavirus-2 or 'SARS-CoV-2' is the causative agent of the novel coronavirus disease (COVID-19), declared a pandemic by WHO. It is a viral strain responsible for widespread damage to human life worldwide [98]. It has been shown that eubiosis has a great influence on the effectiveness of lung immunity [99]. Disruption of the gut microbiota by widespread antibiotic use may have a similar effect observed in population studies showing that increased use of penicillin, cephalosporins, macrolides, and quinolones is associated with an increased risk of lung cancer in humans [100]. A study in mice showed that influenza viral infection in the respiratory tract increased Enterobacteriaceae while decreasing Lactobacilli and Lactococci in the gut microbiota [101]. Considering the results of these studies, it is thought that the role of the intestinal microbiota-lung axis in the development of SARS-Cov2 infection should be investigated [102].

\section{Probiotics and the Immune System}

The Greek word probiotic, which is formed by combining the words "pro bios: for life" is used to describe beneficial microorganisms, especially Lactic acid bacteria (LAB), 
which are beneficial for the microbiota and are non-pathogenic, when taken in sufficient quantities positively affect the health of the individual $[103,104]$. For microorganisms to be used as probiotics, they must have the Generally Recognized as Safe (GRAS) status approved by the Food and Drug Administration (FDA) in the USA and the Qualified Safety Assumption (QPS) developed by European Food Safety Authority (EFSA) in Europe. In addition, they are required to be non-pathogenic and toxic, have positive effects on health proven by studies, have the characteristics of antimicrobial secretion to fight pathogenic microorganisms, adapt to the microbiota, to reach the intestines alive, be non-penetrative to the intestinal epithelium, be temporarily colonized in the GIS, and survive during the shelf life [105-108].

Various interactions occur between different types of bacteria that make up the intestinal microbiota and the immune system. Probiotic bacteria play a role in the regulation of immune response disorder specific to the pathogenesis of diseases by stimulating immune cells such as Th1, Th2, Th17, Treg cells and B cells through the modulation of intestinal microbiota [109]. Bacteria that make up the intestinal microbiota, especially Lactobacilli and Bifidobacteria, show antimicrobial effects by affecting both local and systemic immunity [110]. Bifidobacteria and Lactobacilli prevent the proliferation of pathogenic bacteria by competing with pathogens for nutrients; by stimulating the release of antimicrobial substances, especially mucin (MUC) which activates the MUC 2 and MUC 3 genes and prevents pathogens from adhering to the epithelial barrier; and by inhibiting the pathogens with the antimicrobial molecules they secrete [111]. Literature has shown that orally taken Bifidobacteria and Lactobacilli reduce the allergic-type immune response by increasing the Th cell response, IL-10, and TGF- $\beta$ production and improving immunological tolerance against pathogens [112]. Intestinal microbiota stimulates plasma blasts responsible for IgA production, which is the precursor of $\operatorname{sgA}$ that acts as a protective agent against pathogens and toxins in the intestine [113]. In an animal model, Bifidobacteria and Lactobacilli were administered orally to animals and were found to increase sIgA production [114]. It has been observed that Bifidobacteria given to premature infants positively affect their intestinal microbiota by increasing the amount of SCFA in the stool, decreasing the dominance of Escherichia coli and Bacteriodetes, and decreasing fecal ammonia and indoles [115]. Both human and animal studies have shown that Lactobacillus casei, Lactobacillus bulgaricus, and Lactobacillus acidophilus given as probiotic supplements, increase the formation of macrophages and thus increase the level of phagocytosis [116]. Moreover, L. rhamnosus HN001 and B. lactis HN109 increase the cytotoxic potential and activity of natural killer cells by stimulating the increased production of IL-15 and IL-22 [117].

It is stated that probiotics can be a therapeutic target in the case of diarrhea in patients with dysbiosis developing with the use of antibiotics and antiviral drugs in the treatment of COVID-19 [118]. The National Health Commission of China has approved the use of probiotics for the treatment of patients suffering from intestinal dysbiosis due to COVID-19 infection and for the prevention of secondary bacterial infections that may occur [119]. It is also thought that various probiotic strains such as Enterococcus faecium and Lactobacillus spp. may help maintain intestinal barrier integrity by increasing the production of butyrate, a fuel for colonocytes, which may reduce COVID-19 invasion [120,121]. In a study, it was shown that Bifidobacterium bifidum helped modulate the adaptive immune response in influenza infective mice [122]. Oral administration of Lactobacillus acidophilus CMCC878 24 $\mathrm{h}$ after pulmonary administration of Staphylococcus aureus and Pseudomonas aeruginosa has been reported to reduce systemic inflammation and lung injury in mice [123]. In another study conducted on mice, Lactobacillus gasseri SBT2055 was found to exhibit antiviral and prophylactic activity by stimulating the reduction in proinflammatory cytokine level against infection developing in the case of respiratory syncytial virus [124]. However, more studies are needed due to the lack of sufficient studies in the literature on the effectiveness of probiotics in the treatment and prophylaxis of COVID-19. 


\section{Safety and Possible Side Effects of Probiotics}

Today, probiotic microorganisms are known to mainly belong to groups of lactic acid-producing bacilli (phylum containing different genera including LAB-Streptococcus, Staphylococcus, Lactococcus, Lactobacillus, Enterococcus) and Bifidobacteria groups. For the beneficial effects of probiotic microorganisms to be seen, it is recommended that the number of viable cells reaching the intestine should be at least $10^{6}-10^{7}$ colony-forming units (cfu)/g [125]. However, in most commercial probiotic products, many beneficial microorganisms, especially near the end of their shelf life, lose their "viability" [126]. Therefore, probiotic products are produced to contain more microorganisms (on average 2.5 times) than the number of live probiotic microorganisms written on the label. However, the health effects of these dead microorganisms are not clearly known since no studies have been conducted [127]. The viability of these microorganisms varies depending on many conditions, such as the characteristics of the microorganism, the acidity degree of the product, the storage temperature, and the characteristics of the packaging materials used [128].

In the last three decades, the therapeutic potential of probiotics has been evaluated in many times [129]. With the increasing use of probiotics to treat dysbiosis associated with many diseases, safety problems have also been raised [130]. Although many studies are reporting that the use of probiotics is generally safe, this situation has been questioned with current studies and it has been concluded that "probiotics should be applied in high-risk groups (older adults, hospitalized patients, cancer patients) after careful evaluation of the risk-benefit ratio" [24,131].

Despite various health benefits, research on probiotics have reported that issues such as unknown molecular mechanisms; strain-specific behavior; the difference in the response of probiotics of short-lived, autochthonous (resident or colonized in the host) and allochthonous microorganisms (externally applied such as probiotics); antibiotic resistance that can develop with horizontal gene transfer; maintenance of vitality and stability during the shelf life, although rare; problems such as infective endocarditis, sepsis, bacterial translocation into tissue or blood; and bacteremia in immunocompromised individuals may develop [131-133]. Moreover, it has been reported that live probiotics are affected by host-specific factors in the GIS, which activate various bacterial genes for the degradation and production of nutrients through different metabolic pathways [134,135].

GIS side effects can develop after the use of probiotic supplements, including vomiting, nausea, abdominal spasms, diarrhea, bloating, thirst, and taste disturbance [130]. Such side effects, most of them mild, were reported to occur at a clinical frequency of $28 \%$ as a result of the study [129]. Researchers hypothesize that probiotic administration increases the fermentation of indigestible carbohydrates (SIBO) by overgrowth of bacteria in the proximal small intestine and, as a result, excess D-lactic acid production may cause abdominal bloating with increased gas output [136]. Interestingly, studies found that when probiotics were administered in humans following antibiotic therapy, the increase in probiotic strain-induced colonization in the colon microbiota was associated with persistent or prolonged dysbiosis [131,137].

The latest Cochrane report states that probiotics are successfully used to prevent infectious diarrhea in both children and adults [138]. However, there are also studies reporting cases of bacteremia, sepsis, fungemia, endocarditis, meningitis, endometritis, peritonitis, and pneumonia as a negative consequence of probiotic administration [139]. This pathological phenomenon may develop due to an impaired gut barrier, immunosuppression, or leaky gut conditions [140]. It has been suggested that factors facilitating translocation by probiotics may be linked to the intestinal mucosal adhesion capacity or mucolytic activity [141,142].

In a review to analyze data on the efficacy and safety of probiotic use in cancer patients, the researchers concluded that probiotics may be a rare cause of sepsis, as a case report of five of the seventeen cases included in the analysis found that probiotic-associated bacteremia/fungemia was positive in the blood [143]. At the same time, a meta-analysis 
noted that probiotics are effective in preventing diarrhea caused by chemoradiotherapy in people with abdominal and pelvic cancer, but most cancer patients have a rare risk of sepsis because their immune systems are compromised [144]. In the case of premature infants, which is another potential group at risk, the use of some probiotic strains is recommended in the prevention of dysbiosis caused by necrotizing enterocolitis (NEC), a common disease of premature infants with an incidence ranging from $2.6 \%$ to $28 \%$ among very low birth weight infants [145]. However, studies have shown that there is a risk of development of bacteremia due to the use of probiotics in NEC prophylaxis in premature infants. In a case-control study, it was reported that bacteremia caused by bacterial transformation developed in 3 of 654 premature infants who were treated with probiotics containing $B$. longum and Lactobacillus acidophilus. Results of another case-control study Lactobacillus acidophilus (ATCC 4356) and Bifidobacterium longum spp. infantis (ATCC 15.697), 3 out of 290 premature infants given probiotics were diagnosed with bacteremia [146,147]. The report published by The European Society for Paediatric Gastroenterology Hepatology and Nutrition (ESPGHAN) Nutrition Committee and ESPGHAN Probiotics and Prebiotics Working Group on the safety of the use of probiotics in premature infants emphasizes that the quality assurance of the probiotic product to be used is necessary, that probiotic strains should lack transferable antibiotic resistance genes, and that local microbiologists should be able to detect probiotic bacteremia/fungemia routinely with standard culture methods. The use of some specific Lactobacillus rhamnosus GG strain or specific Bifidobacterium infantis, Bifidobacterium lactis, and Streptococcus thermophilus strains is recommended to reduce NEC rates, provided that all safety conditions are met [148].

\section{Postbiotics}

Evidence suggests that microbial vitality is not required to achieve health benefits as with probiotic supplements and postbiotics produced from probiotics provide similar health benefits to probiotics [149]. Despite various health benefits, postbiotic ingredients derived from probiotics are thought to be promising alternative supplements to eradicate the above-mentioned risky conditions of probiotics [150]. Various researchers have proposed different terminologies to describe postbiotics, such as non-living probiotics (paraprobiotics), inactivated probiotics, non-biotic ones, ghost probiotics, and metabiotics [14,151]. Before ISAPP's definition of postbiotics, in the literature, postbiotics were defined as "non-viable bacterial products or metabolic products obtained from microorganisms with biological activity in the host" and paraprobiotics (also called ghost or inactivated microorganism for which cell components are not broken down and non-living microbial cells) as "crude cell extracts that benefit the human or animal consumer when administered orally or topically in sufficient amounts" [152]. In its panel for postbiotics in 2021, ISAPP defined postbiotics as "the preparation of non-viable microorganisms and/or components that provide health benefits to the host" and emphasized that postbiotics must contain microbial cells or cellular components that have been inactivated with or without metabolites, contributing to the observed health benefits and that in order to qualify a preparation as postbiotic, the microbial composition prior to inactivation must be characterized. It has therefore been suggested that microbial components derived from foods fermented by identified microorganisms, rather than traditional foods fermented by unidentified microorganism cultures, can be identified as postbiotics [153]. The specific effect of probiotics is based on certain dosage levels, but a specific dose for postbiotics such as "it should contain $10^{6}-10^{7} \mathrm{cfu} / \mathrm{g}$ live cells" as specified in probiotics has not been identified [17].

Some postbiotics are cell-free supernatants, vitamins, organic acids, SCFA, secreted proteins/peptides, bacteriocins, neurotransmitters, secreted biosurfactants, amino acids, flavonoids derived from postbiotics (desaminotyrosine, equol daidzein, daidzein, and norathyriol), postbiotics derived from postbiotics (genipin, paeoniflorin, paeoni lactone glycosides, paeonimetabolin I, II, and III), metabolites of probiotic microorganisms such as phenolic-derived postbiotics (equol, urolithins, valerolactones, enterolactone, enterodiolen, and 8-prenylnarenin) and teichoic acids, peptidoglycan-derived muropeptides, molecules 
protruding from the surface (pili, fimbriae, and flagella), exopolysaccharides (EPS), cell surface related proteins, and inactivated/dead/non-viable microbial cell components of probiotics, such as cell wall-bound bio-surfactants [154,155].

Postbiotic production is achieved by inactivating probiotic microorganisms. However, it is emphasized that the inactivation method applied to produce postbiotics and parabiotics should be able to preserve the beneficial effects provided by the living form. In this sense, it has been indicated that it can be produced/obtained using different inactivation methods, including sonication, enzymatic processes, solvent extraction, and chemicals (e.g., formalin) at both laboratory and industrial levels [156] (Figure 1). Regarding this situation, heat treatments are the most widely used methods to inactivate probiotic microorganisms. The temperature and duration of heat inactivation differs depending on the characteristics of microorganisms (e.g., vegetative cell or spores, growth medium, growth stage, water activity, etc.) [157].

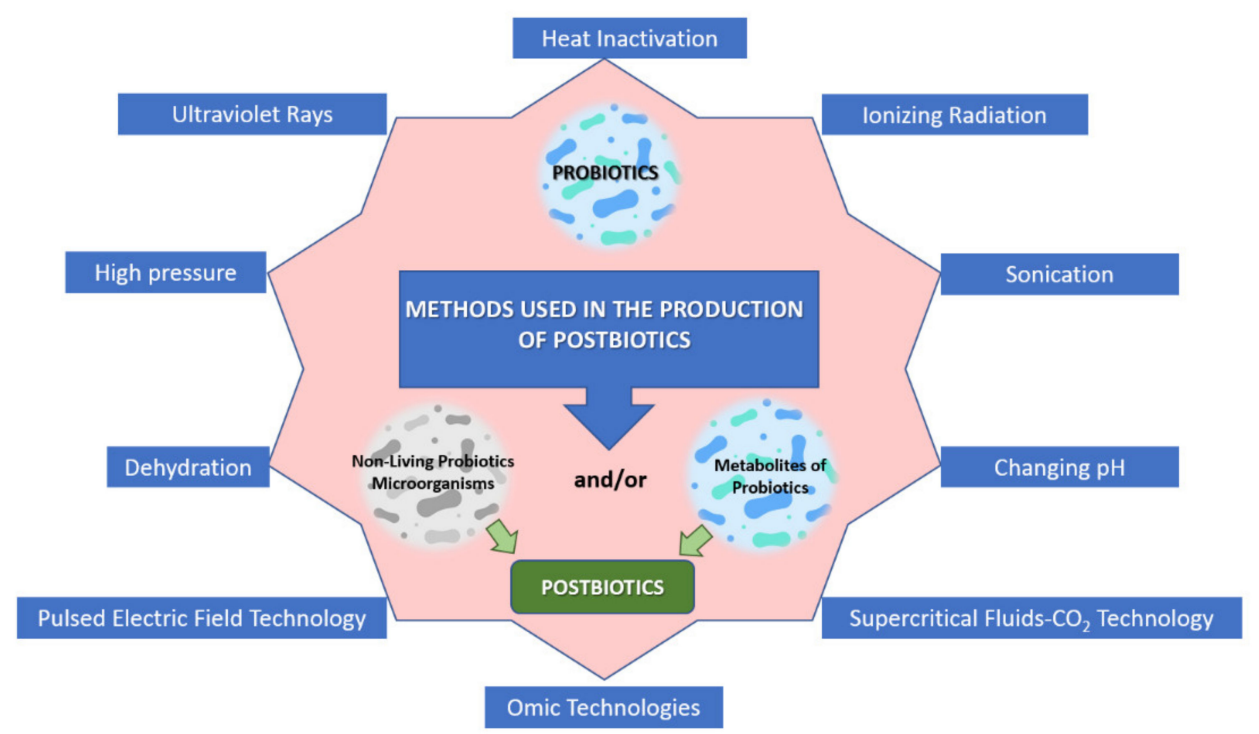

Figure 1. Methods used in the production of postbiotics.

\subsection{Postbiotics and Immune System}

Postbiotics have been mainly associated with immunomodulatory activities, as they play a role in stimulating the innate and adaptive immune system, maintaining the integrity of the intestinal mucosal barrier, and antagonizing pathogens with antimicrobial compounds, such as the effects of probiotics [18]. In this regard, a summary is given to highlight some possible mechanisms of postbiotics in the immune system modulation in Figure 2. 


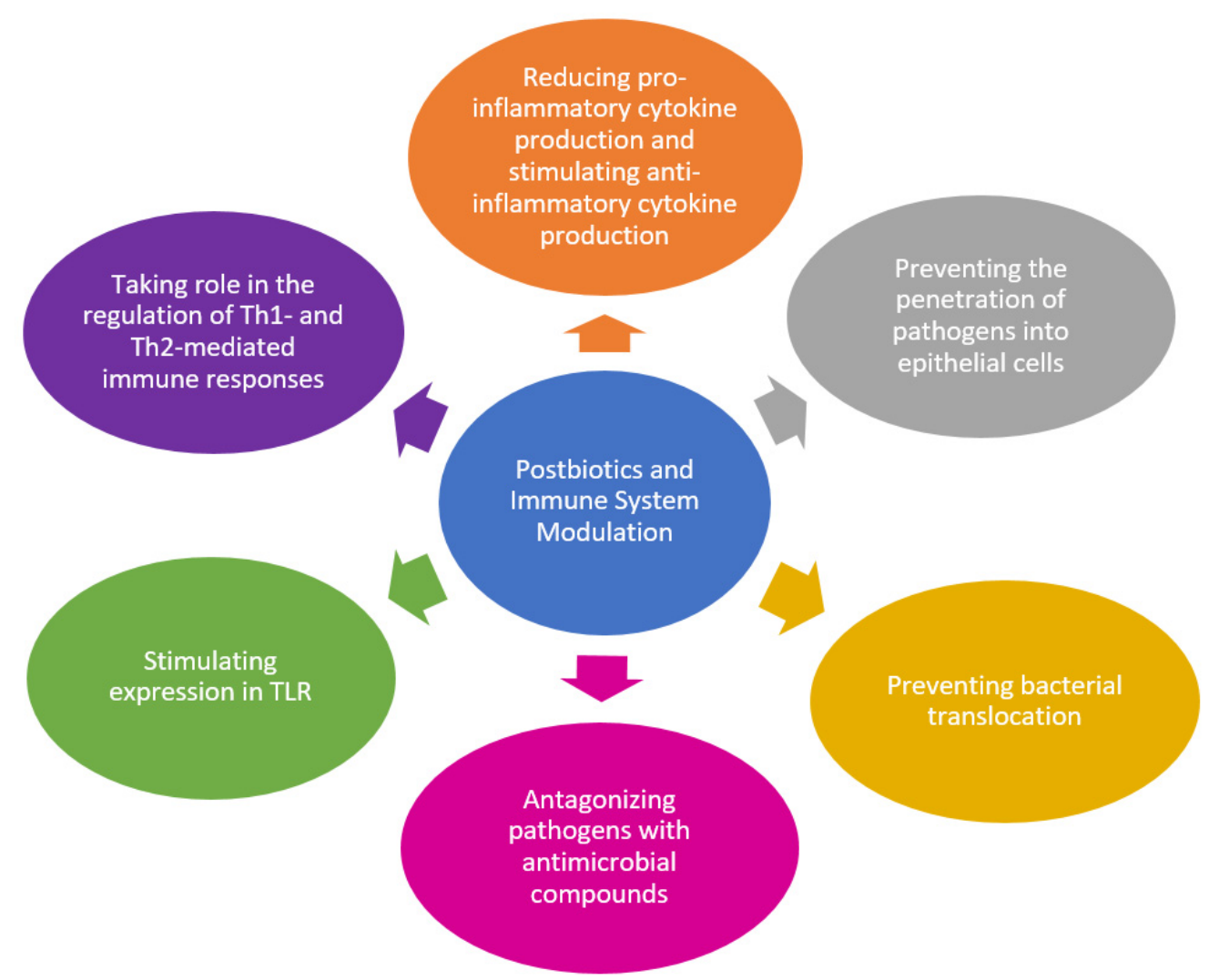

Figure 2. Potential mechanisms and benefits of postbiotics in the immune system modulation.

It is stated that pili and protein $\mathrm{p} 40 / \mathrm{p} 75$, which are postbiotics produced from Lactobacilli, have an immunomodulatory effect by acting on the protection of the intestinal barrier, promoting aggregation, factor proteins, bacteriocins, and S-layer proteins by exhibiting antagonistic activity against pathogens [158]. It appears that the immunostimulant activity of different bacterial species and strains is associated with variations in cell wall components such as lipoteichoic acid and peptidoglycan. It has been suggested that the mechanism by which these bacteria perform their immunomodulating activities is to increase Th1-associated cytokine levels and decrease Th2-related cytokines [159]. In a study, peptidoglycans obtained from different Lactobacillus species (Lactobacillus acidophilus, Lactobacillus rhamnosus, and Lactobacillus casei) increased the capacity to inhibit the release of inflammatory cytokines in macrophage-like cell models via the LPS-induced TLR-4 pathway [160]. On the other hand, in in vitro models of the intestinal mucosa (HT29-MTX cells), heat-inactivated probiotic strains combination including Lactobacillus acidophilus, Lactobacillus plantarum, Lactobacillus casei, Lactobacillus rhamnosus, Bifidobacterium bifidum, Streptococcus thermophilus, and Saccharomyces boulardii protected intestinal cells from Escherichia coli infection by preventing the increase in paracellular permeability and the penetration of pathogens into the intestinal epithelium, ensuring the restoration of tight-junction function and membrane integrity and by modulating cytokine gene expression [161]. In another study, it was reported that the probiotic strain Streptococcus thermophilus CRL1190 and its EPS reduces Helicobacter pylori adhesion and suppresses the inflammatory response in the human gastric adenocarcinoma epithelial cell line (AGS cells). With these findings, it has been suggested that $S$. thermophilus and postbiotics can protect the gastric mucosa and improves the anti-inflammatory response through modulation of cytokine IL-8 production [162]. In a study, the effect of oral treatment with parabiotic Saccharomyces boulardii (heat inactivated-109 cfu/mL $\mathrm{mL}^{-1}$ ) was evaluated in a murine intestinal obstruction (IO) model. The results showed that heat-killed $S$. boulardii administration was able to preserve the gut barrier $(p<0.05)$ by maintaining intestinal permeability at physiological levels and reducing bacterial translocation (to Escherichia coli ATCC 10536) and mucosal lesions [163]. 
Likewise, in another study, researchers demonstrated that metabolic products (postbiotics) of an infant formula fermented with Lactobacillus paracasei CBA L74 can protect the host from pathobionts and enteric pathogens by inhibiting immune cell inflammation and have protective effects against colitis [164]. On the other hand, the researchers investigated the potential of a postbiotic (a new secretory protein called HM0539) produced by Lactobacillus rhamnosus GG in the prevention and treatment of diseases related to intestinal barrier dysfunction by orally administering it to newborn rats infected with Escherichia coli K1 and reported that HM0539 promotes the development of neonatal intestinal defense and is sufficient to prevent Escherichia coli K1 pathogenesis. They also found that HM0539 has the potential to prevent dextran sulfate sodium (DSS)-induced colitis, LPS/D-galactosamineinduced bacterial translocation, and liver damage. As a result, products without live bacteria have been reported to exhibit similar effects, without the need for probiotic cell viability [165].

Moreover, it was found that the immunomodulatory activity of postbiotics produced via inactivation of probiotics was higher than probiotics. For example, the production of heat shock proteins (Hsp) during the heating process appears to increase immunomodulation activity [156]. Postbiotic Lactobacillus casei Zhang (LcZ) (heat inactivated and suspended at $10^{6} \mathrm{cfu} / \mathrm{mL}$ in PBS) enhances the expression of proinflammatory cytokines and the transcription of TLR2, TLR3, TLR4, and TLR9, thus increasing the macrophage-mediated innate immune response [166]. As a result of the study conducted with the live and inactive forms of Bacillus amyloliquefaciens FPTB16 and Bacillus subtilis FPTB13, it was reported that the inactive preparation increased the secretion of cellular immune parameters more than the live preparation [167]. In addition, a study in mice reported that the combination of heat-inactivated (two heat treatments were applied: $30 \mathrm{~min}$ at $100{ }^{\circ} \mathrm{C}$ and $15 \mathrm{~min}$ at $121^{\circ} \mathrm{C}$ ) LAB increased immunomodulatory activity in macrophages more than the same combination (Lactobacillus acidophilus, Lactobacillus plantarum, Lactobacillus fermentum, and Enterococcus faecium) containing live strains [168]. In a study, it was found that Enterococcus gallinarum L-1 postbiotics inactivated by ultraviolet (UV) rays $(2.5 \mathrm{~h})$ were more effective in enhancing the phagocyte activity than heat-inactivated (for $2 \mathrm{~h} 60^{\circ} \mathrm{C}$ ) [156]. Both probiotic and postbiotic Lactobacillus gasseri TMC0356 show an in vitro immunomodulation effect. Compared to probiotics, postbiotic Lactobacillus gasseri TMC 0356 causes a greater increase in IL-12 production in macrophages, indicating that heat treatment increases the ability of the strain to activate IL-12 production in macrophages, thus the postbiotic form has a higher immunomodulatory effect than the probiotic [169]. Lactobacillus acidophilus A2, Lactobacillus gasseri A5, and Lactobacillus salivarius A6 (heat-inactivated and suspended at $10^{6}$ cells $/ \mathrm{mL}$ in PBS) are also postbiotics with in vitro immunomodulating activity. These non-living microorganisms caused changes in Th1-mediated immune response by stimulating IL-10 and IL-12 p70 proliferation, IFN-yproduction in splenocytes, and IL-12 p70 secretion in dendritic cells, respectively. The mechanisms that LAB strains cause different responses in dendritic cells are still unknown, but the immunomodulation response appears to be strain-dependent [170].

As a result, postbiotics and parabiotics show immunomodulatory activity and this provides health benefits to the host. Therefore, they may be safer alternatives for immunocompromised individuals such as the elderly, transplanted patients, and premature neonates and can eliminate the various disadvantages of probiotics (Figure 3) [171-174]. 


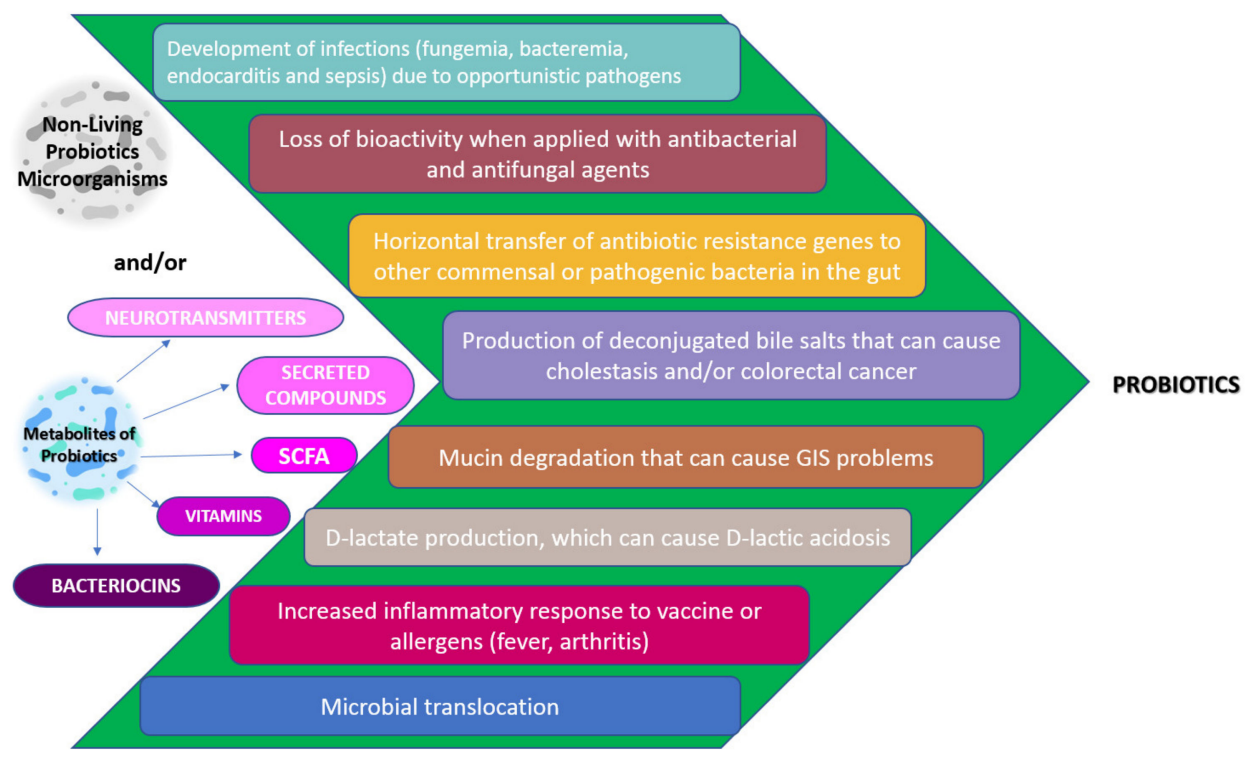

Figure 3. Some disadvantages of probiotics for microbiota and immune system.

\subsection{The Use of Postbiotics in the Food and Pharmaceutical Industry}

The viability of probiotics is one of the key parameters in the development of probiotic products. The health efficacy of probiotic foods depends on the number of viable and active cells per gram or milliliter at the time of consumption [175]. The main factors affecting the stabilization of probiotics in foods are fermentation conditions ( $\mathrm{pH}$ and acidity, temperature, and oxygen); food matrix ( $\mathrm{pH}$, titratable acidity, oxygen, water activity, salt presence, etc.); microencapsulation; additives; food processing (drying, freezing, and thawing); and packaging and storage conditions [176]. For example, probiotic fortified juice can show significant reductions in viable bacteria count during storage due to its high acidity [177]. Considering these factors, postbiotics offer therapeutic and technological advantages for food manufacturers over probiotics for industrial uses [178].

In addition to the therapeutic advantages, some postbiotics are also used for their technological functions that positively affect the physicochemical and sensory properties of the final product, providing better stability, texture, and flavor [179]. Regarding this application, it has been reported that EPS obtained from Streptococcus thermophilus zlw TM11 and Lactobacillus delbrueckii spp. Bulgaricus, respectively, can overcome the problem of syneresis (lower whey separation) and provide better texture and sensory properties during yoghurt preparation [180]. The use of EPS is an alternative to synthetic food additives (viscosifiers, texturizers, and emulsifiers). In another study, the researchers demonstrated that the bacteriocin (BacTN635) postbiotic from Lactobacillus plantarum TN635 could delay microbial proliferation (aerobic, psychrotrophic, and Enterobacteriaceae counts) and suppress the growth of the pathogen Listeria monocytogenes in beef and chicken breast [181]. Bacteriocin has also been reported to extend the shelf life of chilled products and improve sensory quality (odor, texture, color, and general acceptance) and texture qualities (hardness, elasticity, and hardness) [182]. Similarly, in another study, when cell-free supernatant CFS Cys5-4 obtained from Lactobacillus plantarum Cys5-4 was applied to fresh orange and chicha beverages, it was found that for a 5 day storage period CFS Cys5-4 have been found to exhibit antimicrobial activity against living cells found in Escherichia coli at $4{ }^{\circ} \mathrm{C}$ and Salmonella [183]. In a relevant study, it was reported that the cell-free supernatant obtained from Lactobacillus sp.RM1 showed antifungal activity against Aspergillus parasiticus, Aspergillus flavus, and Aspergillus carbonarius and inhibited aflatoxin B1 and ochratoxin A [184].

Some evidence in the literature have been conducted on food products containing commercial postbiotics for health/therapeutic applications. LAC-Shield ${ }^{\mathrm{TM}}$ (Morinaga Milk Industry Co., Ltd., Tokyo, Japan) has commercially proven that heat-inactivated Lactobacil- 
lus paracasei MCC1849 (LAC-Shield ${ }^{\circledR}$ ) is effective for improving the resistance of postbiotic chocolate to cold infections [185]. Staimune ${ }^{\circledR}$ (Blossom Water LLC., Westwood, MA, USA) is a patented probiotic-derived ingredient containing inactivated GanedenBC $30^{\circledR}$ (Bacillus coagulans GBI-30). This postbiotic is found in Blossom Water ${ }^{\circledR}$ beverages. It has been proven that Ganeden $B C 30^{\circledR}$ s cell wall and metabolite fractions inhibit spontaneous and oxidative stress-induced reactive oxygen species (ROS) formation in human peripheral blood mononuclear cells (PBMC) (anti-inflammatory effect) and induces the production of Th2 cytokines IL-4, IL-6, and IL-10 [186]. Colimil ${ }^{\circledR}$ Baby (Humana Spain SL, Madrid, Spain), a formula containing Matricaria chamomilla L., Melissa officinalis L., and heat-inactivated Lactobacillus acidophilus HA122, have been shown to help prevent colic (IC) in infants [187]. Lacteol $^{\mathrm{TM}}$ (Reig Jofre, S.A., Barcelona, Spain), a postbiotic product prepared from heatinactivated Lactobacillus acidophilus LB cells, has been reported to be effective in the treatment of acute and chronic diarrhea associated with various intestinal infectious diseases. In vitro and in vivo studies support that $L$. acidophilus $L B$ administration exhibits antibacterial activities, including antibiotic-like and cell-regulating activities [188]. Del-Immune $\mathrm{V}^{\circledR}$ (Pure Research Products LLC., Boulder, CO, USA) is a postbiotic supplement containing cell lysate (muramil peptides) and DNA fragments of the probiotic strain Lactobacillus rhamnosus V (DV). Experimental clinical studies demonstrated that this product is effective in stimulating the innate immune system mainly through induction of the production of cytokines IFN- $\gamma$, TNF- $\alpha$ and IL-1, IL-2, IL-6, IL-8, and IL-12 [189]. Hylak ${ }^{\circledR}$ Forte (Ratiopharm/Merckle $\mathrm{GmbH}$, Blaubeuren, Germany) is a postbiotic liquid containing metabolic products (e.g., SCFA, amino acids, and vitamins) derived from Lactobacillus helveticus DS 4183, Escherichia coli DSM 4087, Streptococcus faecalis DSM 4086, and Lactobacillus acidophilus DSM 414. It is prescribed for the treatment of bacterial imbalance in the GIS and associated symptoms (e.g., bloating, diarrhea, and constipation) as it inhibits the growth of pathogenic bacteria by lowering the intestinal lumen $\mathrm{pH}$ [190]. Given the advantages of postbiotics compared to probiotics, further studies are needed on their use and health benefits in the food and pharmaceutical industry.

\section{Conclusions and Recommendations}

In conclusion, it has been shown in many studies that microorganisms colonized in many regions of our body, especially the intestines, live with us within the framework of mutual benefit; interact with other systems, especially the immune system, which defends our body against pathogens; and plays a role in the pathogenesis of various diseases such as obesity, diabetes mellitus, liver diseases, celiac disease, cancer, cardiovascular diseases, inflammatory bowel diseases as well as the immune system modulation.

The intestinal microbiota, together with other immune system components are involved in the development of the immune response. Considering the impact of intestinal microbiota on health and disease, scientific and commercial interest has increased in the use of probiotics that stimulate the modulation of the intestinal microbiota for improving health and diseases treating immune system. Despite the health benefits of probiotics, concerns about their use have also arisen since they are affected by various properties of the products they are used in (shelf life, food additives, product matrix, etc.), causing microbial translocation and the possibility of developing antibiotic resistance in the established intestinal microbiota. In order to eliminate these disadvantages, studies on inactivated microorganisms and/or their metabolites have increased in the recent years since they provide their health benefits through some bioactive components (EPS, teichoic acid, SCFA, amino acids, cell wall components, secreted peptides, etc.) and their nonliving forms.

At this time, it was noted that these components nominated as parabiotics and/or postbiotics show immunomodulatory activity by various mechanisms. Similar to the effects of probiotics, they have been mainly associated with immunomodulatory activities by playing a role in maintaining the integrity of the intestinal mucosal barrier and antagonizing pathogens with antimicrobial compounds by stimulating the natural and adaptive immune system, but the immunomodulation response still appears to be strain dependent. However, 
when considering the current data in the literature, it can be said that large randomised controlled clinical trials could provide more definitive evidence.

In addition to eliminating the disadvantages of probiotics for microbiota and the immune system, postbiotics can also reduce the use of food additives because they act as emulsifiers and preservatives in ensuring the stability of the products they are used. There is also some evidence about immunomodulatory and the therapeutic effects regarding products containing commercial postbiotics. Although the use of them in the food and pharmaceutical industry is promising, more studies are required to avoid the side effects and disadvantages that may occur with the use of products containing probiotics, especially in people with a weak immune system.

Author Contributions: N.Y. and B.Y.: Drafted the work or revised it critically for important intellectual content; provided the final approval of the version to be published. D.A. and R.C.: designed and drafted the work and revised it critically for important intellectual content; provided the final approval of the version to be published. All authors have read and agreed to the published version of the manuscript.

Funding: This research received no external funding.

Data Availability Statement: No new data were created or analyzed in this study. Data sharing is not applicable to this article.

Conflicts of Interest: The authors declare no conflict of interest.

\section{References}

1. Doan, T.; Melvold, R.; Viselli, S.; Waltenbaugh, C. Lippincott's Illustrated Reviews: Immunology. In The Need to Know Your Self; Harvey, R.A., Ed.; Nobel Tip Kitabevleri: İstanbul, Turkey, 2017; pp. 3-10.

2. Pradeu, T.; Cooper, E.L. The danger theory: 20 years later. Front. Immunol. 2012, 3, 287. [CrossRef]

3. Seong, S.Y.; Matzinger, P. Hydrophobicity: An ancient damage-associated molecular pattern that initiates innate immune responses. Nat. Rev. Immunol. 2004, 4, 469-478. [CrossRef] [PubMed]

4. Mowat, A.M.; Viney, J.L. The anatomical basis of intestinal immunity. Immunol. Rev. 1997, 156, 145-166. [CrossRef] [PubMed]

5. Aristizábal, B.; González, Á. Innate immune system. In Autoimmunity: From Bench to Bedside [Internet]; El Rosario University Press: Bogota, Colombia, 2013.

6. Hooper, L.V.; Littman, D.R.; Macpherson, A.J. Interactions between the microbiota and the immune system. Science 2012, 336, 1268-1273. [CrossRef] [PubMed]

7. Herrema, H.; RG, I.J.; Nieuwdorp, M. Emerging role of intestinal microbiota and microbial metabolites in metabolic control. Diabetologia 2017, 60, 613-617. [CrossRef] [PubMed]

8. Anwar, H.; Irfan, S.; Hussain, G.; Faisal, M.N.; Muzaffar, H.; Mustafa, I.; Mukhtar, I.; Malik, S.; Ullah, M.I. Gut microbiome: A new organ system in body. In Parasitology and Microbiology Research; IntechOpen: London, UK, 2019; pp. 1-20.

9. Whitman, W.B.; Coleman, D.C.; Wiebe, W.J. Prokaryotes: The unseen majority. Proc. Natl. Acad. Sci. USA 1998, 95, 6578-6583. [CrossRef] [PubMed]

10. Atılgan, A.E.; Genç, A.C.; Yavaş, A.M.; Eminler, A.T.; Uygun, A.; Tanoğlu, A.; Gündoğdu, A.; Kaya, A.; Erdoğan, A.; Dikicier, B.S.; et al. Mikrobiyota, Probiyotikler ve Akılcı Beslenme; Nobel Akademik Yayıncılık: Ankara, Turkey, 2020.

11. Hill, C.; Guarner, F.; Reid, G.; Gibson, G.R.; Merenstein, D.J.; Pot, B.; Morelli, L.; Canani, R.B.; Flint, H.J.; Salminen, S.; et al. Expert consensus document. The International Scientific Association for Probiotics and Prebiotics consensus statement on the scope and appropriate use of the term probiotic. Nat. Rev. Gastroenterol. Hepatol. 2014, 11, 506-514. [CrossRef]

12. Gibson, G.R.; Hutkins, R.; Sanders, M.E.; Prescott, S.L.; Reimer, R.A.; Salminen, S.J.; Scott, K.; Stanton, C.; Swanson, K.S.; Cani, P.D.; et al. Expert consensus document: The International Scientific Association for Probiotics and Prebiotics (ISAPP) consensus statement on the definition and scope of prebiotics. Nat. Rev. Gastroenterol. Hepatol. 2017, 14, 491-502. [CrossRef] [PubMed]

13. Swanson, K.S.; Gibson, G.R.; Hutkins, R.; Reimer, R.A.; Reid, G.; Verbeke, K.; Scott, K.P.; Holscher, H.D.; Azad, M.B.; Delzenne, N.M.; et al. The International Scientific Association for Probiotics and Prebiotics (ISAPP) consensus statement on the definition and scope of synbiotics. Nat. Rev. Gastroenterol. Hepatol. 2020, 17, 687-701. [CrossRef]

14. Malashree, L.; Angadi, V.; Yadav, S.; Prabha, R. "Postbiotics"-One Step Ahead of Probiotics. Int. J. Curr. Microbiol. Appl. Sci. 2019, 8, 2049-2053. [CrossRef]

15. Collado, M.C.; Vinderola, G.; Salminen, S. Postbiotics: Facts and open questions. A position paper on the need for a consensus definition. Benef. Microbes 2019, 10, 711-719. [CrossRef] [PubMed]

16. Fair, W.R.; Couch, J.; Wehner, N. Prostatic antibacterial factor. Identity and significance. Urology 1976, 7, 169-177. [CrossRef]

17. Singh, A.; Vishwakarma, V.; Singhal, B. Metabiotics: The Functional Metabolic Signatures of Probiotics: Current State-of-Art and Future Research Priorities-Metabiotics: Probiotics Effector Molecules. Adv. Biosci. Biotechnol. 2018, 09, 147-189. [CrossRef] 
18. De Marco, S.; Sichetti, M.; Muradyan, D.; Piccioni, M.; Traina, G.; Pagiotti, R.; Pietrella, D. Probiotic Cell-Free Supernatants Exhibited Anti-Inflammatory and Antioxidant Activity on Human Gut Epithelial Cells and Macrophages Stimulated with LPS. Evid. Based Complement. Altern. Med. 2018, 2018, 1756308. [CrossRef] [PubMed]

19. Chaplin, D.D. Overview of the immune response. J. Allergy Clin. Immunol. 2010, 125, S3-S23. [CrossRef] [PubMed]

20. Abbas, A.K.; Lichtman, A.H.; Pillai, S. Cellular and Molecular Immunology; Abbas, A.K., Lichtman, A.H., Pillai, S., Eds.; Saunders/Elsevier: Philadelphia, PA, USA, 2014.

21. Chinen, J.; Shearer, W.T. Basic and clinical immunology. J. Allergy Clin. Immunol. 2005, 116, 411-418. [CrossRef]

22. Grice, E.A.; Segre, J.A. The skin microbiome. Nat. Rev. Microbiol. 2011, 9, 244-253. [CrossRef]

23. Ottman, N.; Smidt, H.; de Vos, W.M.; Belzer, C. The function of our microbiota: Who is out there and what do they do? Front. Cell Infect. Microbiol. 2012, 2, 104. [CrossRef]

24. Kothari, D.; Patel, S.; Kim, S.K. Probiotic supplements might not be universally-effective and safe: A review. Biomed. Pharm. 2019, 111, 537-547. [CrossRef]

25. Barton, G.M. A calculated response: Control of inflammation by the innate immune system. J. Clin. Investig. 2008, 118, 413-420. [CrossRef]

26. Lubbers, R.; van Essen, M.; Kooten, C.; Trouw, L. Production of complement components by cells of the immune system. Clin. Exp. Immunol. 2017, 188. [CrossRef] [PubMed]

27. Podolsky, D.K.; Gerken, G.; Eyking, A.; Cario, E. Colitis-associated variant of TLR2 causes impaired mucosal repair because of TFF3 deficiency. Gastroenterology 2009, 137, 209-220. [CrossRef]

28. Heinrich, V.; Lee, C.-Y. Blurred line between chemotactic chase and phagocytic consumption: An immunophysical single-cell perspective. J. Cell Sci. 2011, 124, 3041-3051. [CrossRef]

29. Schaper, F.; Rose-John, S. Interleukin-6: Biology, signaling and strategies of blockade. Cytokine Growth Factor Rev. 2015, 26, 475-487. [CrossRef] [PubMed]

30. Bachmann, M.F.; Kopf, M. Balancing protective immunity and immunopathology. Curr. Opin. Immunol. 2002, 14, 413-419. [CrossRef]

31. Abbas, A.K.; Murphy, K.M.; Sher, A. Functional diversity of helper T lymphocytes. Nature 1996, 383, 787-793. [CrossRef]

32. Delves, P.J.; Roitt, I.M. The immune system. Second of two parts. N. Engl. J. Med. 2000, 343, 108-117. [CrossRef] [PubMed]

33. McHeyzer-Williams, L.J.; Malherbe, L.P.; McHeyzer-Williams, M.G. Helper T cell-regulated B cell immunity. Curr. Top. Microbiol. Immunol. 2006, 311, 59-83. [CrossRef]

34. Mullington, J.M.; Hinze-Selch, D.; Pollmächer, T. Mediators of inflammation and their interaction with sleep: Relevance for chronic fatigue syndrome and related conditions. Ann. N. Y. Acad. Sci. 2001, 933, 201-210. [CrossRef]

35. Tang, Q.; Bluestone, J.A. The Foxp3+ regulatory T cell: A jack of all trades, master of regulation. Nat. Immunol. 2008, 9, 239-244. [CrossRef]

36. Tesmer, L.A.; Lundy, S.K.; Sarkar, S.; Fox, D.A. Th17 cells in human disease. Immunol. Rev. 2008, 223, 87-113. [CrossRef]

37. Corthay, A. How do regulatory T cells work? Scand. J. Immunol. 2009, 70, 326-336. [CrossRef] [PubMed]

38. Beutler, B.; Jiang, Z.; Georgel, P.; Crozat, K.; Croker, B.; Rutschmann, S.; Du, X.; Hoebe, K. Genetic analysis of host resistance: Toll-like receptor signaling and immunity at large. Annu. Rev. Immunol. 2006, 24, 353-389. [CrossRef] [PubMed]

39. Akira, S.; Takeda, K. Toll-like receptor signalling. Nat. Rev. Immunol. 2004, 4, 499-511. [CrossRef]

40. Takeda, K.; Kaisho, T.; Akira, S. Toll-like receptors. Annu. Rev. Immunol. 2003, 21, 335-376. [CrossRef]

41. Murillo, L.S.; Morré, S.A.; Peña, A.S. Toll-like receptors and NOD/CARD proteins: Pattern recognition receptors are key elements in the regulation of immune response. Drugs Today 2003, 39, 415-438. [CrossRef]

42. Medzhitov, R. Recognition of microorganisms and activation of the immune response. Nature 2007, 449, 819-826. [CrossRef]

43. O'Neill, L.A.; Bowie, A.G. The family of five: TIR-domain-containing adaptors in Toll-like receptor signalling. Nat. Rev. Immunol. 2007, 7, 353-364. [CrossRef] [PubMed]

44. Otte, J.M.; Cario, E.; Podolsky, D.K. Mechanisms of cross hyporesponsiveness to Toll-like receptor bacterial ligands in intestinal epithelial cells. Gastroenterology 2004, 126, 1054-1070. [CrossRef] [PubMed]

45. Jandhyala, S.M.; Talukdar, R.; Subramanyam, C.; Vuyyuru, H.; Sasikala, M.; Nageshwar Reddy, D. Role of the normal gut microbiota. World J. Gastroenterol. 2015, 21, 8787-8803. [CrossRef]

46. Biragyn, A.; Ruffini, P.A.; Leifer, C.A.; Klyushnenkova, E.; Shakhov, A.; Chertov, O.; Shirakawa, A.K.; Farber, J.M.; Segal, D.M.; Oppenheim, J.J.; et al. Toll-like receptor 4-dependent activation of dendritic cells by beta-defensin 2. Science 2002, 298, 1025-1029. [CrossRef]

47. Cario, E.; Podolsky, D.K. Differential alteration in intestinal epithelial cell expression of toll-like receptor 3 (TLR3) and TLR4 in inflammatory bowel disease. Infect. Immunol. 2000, 68, 7010-7017. [CrossRef]

48. Abreu, M.T. Toll-like receptor signalling in the intestinal epithelium: How bacterial recognition shapes intestinal function. Nat. Rev. Immunol. 2010, 10, 131-144. [CrossRef]

49. Adak, A.; Khan, M.R. An insight into gut microbiota and its functionalities. Cell Mol. Life Sci. 2019, 76, 473-493. [CrossRef]

50. Deplancke, B.; Gaskins, H.R. Microbial modulation of innate defense: Goblet cells and the intestinal mucus layer. Am. J. Clin. Nutr. 2001, 73, 1131S-1141S. [CrossRef] [PubMed]

51. Sankar, S.A.; Lagier, J.C.; Pontarotti, P.; Raoult, D.; Fournier, P.E. The human gut microbiome, a taxonomic conundrum. Syst. Appl. Microbiol. 2015, 38, 276-286. [CrossRef] 
52. Burgueño, J.F.; Abreu, M.T. Epithelial Toll-like receptors and their role in gut homeostasis and disease. Nat. Rev. Gastroenterol. Hepatol. 2020, 17, 263-278. [CrossRef] [PubMed]

53. Takeuchi, O.; Sato, S.; Horiuchi, T.; Hoshino, K.; Takeda, K.; Dong, Z.; Modlin, R.L.; Akira, S. Cutting edge: Role of Toll-like receptor 1 in mediating immune response to microbial lipoproteins. J. Immunol. 2002, 169, 10-14. [CrossRef] [PubMed]

54. Aliprantis, A.O.; Yang, R.B.; Mark, M.R.; Suggett, S.; Devaux, B.; Radolf, J.D.; Klimpel, G.R.; Godowski, P.; Zychlinsky, A. Cell activation and apoptosis by bacterial lipoproteins through toll-like receptor-2. Science 1999, 285, 736-739. [CrossRef] [PubMed]

55. Schwandner, R.; Dziarski, R.; Wesche, H.; Rothe, M.; Kirschning, C.J. Peptidoglycan- and lipoteichoic acid-induced cell activation is mediated by toll-like receptor 2. J. Biol. Chem. 1999, 274, 17406-17409. [CrossRef] [PubMed]

56. Alexopoulou, L.; Holt, A.C.; Medzhitov, R.; Flavell, R.A. Recognition of double-stranded RNA and activation of NF-kappaB by Toll-like receptor 3. Nature 2001, 413, 732-738. [CrossRef] [PubMed]

57. Poltorak, A.; He, X.; Smirnova, I.; Liu, M.Y.; van Huffel, C.; Du, X.; Birdwell, D.; Alejos, E.; Silva, M.; Galanos, C.; et al. Defective LPS signaling in C3H/HeJ and C57BL/10ScCr mice: Mutations in Tlr4 gene. Science 1998, 282, 2085-2088. [CrossRef] [PubMed]

58. Hayashi, F.; Smith, K.D.; Ozinsky, A.; Hawn, T.R.; Yi, E.C.; Goodlett, D.R.; Eng, J.K.; Akira, S.; Underhill, D.M.; Aderem, A. The innate immune response to bacterial flagellin is mediated by Toll-like receptor 5. Nature 2001, 410, 1099-1103. [CrossRef]

59. Takeuchi, O.; Kawai, T.; Mühlradt, P.F.; Morr, M.; Radolf, J.D.; Zychlinsky, A.; Takeda, K.; Akira, S. Discrimination of bacterial lipoproteins by Toll-like receptor 6. Int. Immunol. 2001, 13, 933-940. [CrossRef] [PubMed]

60. Sender, R.; Fuchs, S.; Milo, R. Are We Really Vastly Outnumbered? Revisiting the Ratio of Bacterial to Host Cells in Humans. Cell 2016, 164, 337-340. [CrossRef]

61. Martin, R.; Makino, H.; Cetinyurek Yavuz, A.; Ben-Amor, K.; Roelofs, M.; Ishikawa, E.; Kubota, H.; Swinkels, S.; Sakai, T.; Oishi, K.; et al. Early-Life Events, Including Mode of Delivery and Type of Feeding, Siblings and Gender, Shape the Developing Gut Microbiota. PLoS ONE 2016, 11, e0158498. [CrossRef]

62. International Consortium Completes Human Genome Project. Available online: https://www.genome.gov/11006929/2003release-international-consortium-completes-hgp (accessed on 15 May 2021).

63. Thursby, E.; Juge, N. Introduction to the human gut microbiota. Biochem. J. 2017, 474, 1823-1836. [CrossRef]

64. Bazett, M.; Bergeron, M.-E.; Haston, C.K. Streptomycin treatment alters the intestinal microbiome, pulmonary T cell profile and airway hyperresponsiveness in a cystic fibrosis mouse model. Sci. Rep. 2016, 6, 19189. [CrossRef]

65. Lynch, S.V.; Pedersen, O. The Human Intestinal Microbiome in Health and Disease. N. Engl. J. Med. 2016, 375, 2369-2379. [CrossRef]

66. Millar, M.; Wilks, M.; Costeloe, K. Probiotics for preterm infants? Arch. Dis. Child. Fetal Neonatal Ed. 2003, 88, F354-F358. [CrossRef]

67. Perez-Muñoz, M.E.; Arrieta, M.C.; Ramer-Tait, A.E.; Walter, J. A critical assessment of the "sterile womb" and "in utero colonization" hypotheses: Implications for research on the pioneer infant microbiome. Microbiome 2017, 5, 48. [CrossRef]

68. Fricke, W.F.; Ravel, J. Microbiome or no microbiome: Are we looking at the prenatal environment through the right lens? Microbiome 2021, 9, 9. [CrossRef] [PubMed]

69. Gill, H.S.; Rutherfurd, K.J.; Cross, M.L. Dietary probiotic supplementation enhances natural killer cell activity in the elderly: An investigation of age-related immunological changes. J. Clin. Immunol. 2001, 21, 264-271. [CrossRef] [PubMed]

70. Ogawa, T.; Asai, Y.; Tamai, R.; Makimura, Y.; Sakamoto, H.; Hashikawa, S.; Yasuda, K. Natural killer cell activities of synbiotic Lactobacillus casei ssp. casei in conjunction with dextran. Clin. Exp. Immunol. 2006, 143, 103-109. [CrossRef] [PubMed]

71. Zheng, W.; Zhao, W.; Wu, M.; Song, X.; Caro, F.; Sun, X.; Gazzaniga, F.; Stefanetti, G.; Oh, S.; Mekalanos, J.J.; et al. Microbiotatargeted maternal antibodies protect neonates from enteric infection. Nature 2020, 577, 543-548. [CrossRef] [PubMed]

72. Latuga, M.S.; Stuebe, A.; Seed, P.C. A review of the source and function of microbiota in breast milk. Semin. Reprod. Med. 2014, 32, 68-73. [CrossRef]

73. Le Doare, K.; Holder, B.; Bassett, A.; Pannaraj, P.S. Mother's Milk: A Purposeful Contribution to the Development of the Infant Microbiota and Immunity. Front. Immunol. 2018, 9, 361. [CrossRef] [PubMed]

74. Boudry, G.; Charton, E.; Le Huerou-Luron, I.; Ferret-Bernard, S.; Le Gall, S.; Even, S.; Blat, S. The Relationship Between Breast Milk Components and the Infant Gut Microbiota. Front. Nutr. 2021, 8. [CrossRef]

75. Murphy, E.A.; Velazquez, K.T.; Herbert, K.M. Influence of high-fat diet on gut microbiota: A driving force for chronic disease risk. Curr. Opin. Clin. Nutr. Metab. Care 2015, 18, 515-520. [CrossRef]

76. Splichalova, A.; Slavikova, V.; Splichalova, Z.; Splichal, I. Preterm Life in Sterile Conditions: A Study on Preterm, Germ-Free Piglets. Front. Immunol. 2018, 9. [CrossRef] [PubMed]

77. Sirisinha, S. The potential impact of gut microbiota on your health:Current status and future challenges. Asian Pac. J. Allergy Immunol. 2016, 34, 249-264. [CrossRef]

78. Pandiyan, P.; Bhaskaran, N.; Zou, M.; Schneider, E.; Jayaraman, S.; Huehn, J. Microbiome Dependent Regulation of T(regs) and Th17 Cells in Mucosa. Front. Immunol. 2019, 10, 426. [CrossRef]

79. Schulthess, J.; Pandey, S.; Capitani, M.; Rue-Albrecht, K.C.; Arnold, I.; Franchini, F.; Chomka, A.; Ilott, N.E.; Johnston, D.G.W.; Pires, E.; et al. The Short Chain Fatty Acid Butyrate Imprints an Antimicrobial Program in Macrophages. Immunity 2019, 50, 432-445.e7. [CrossRef]

80. Peterson, J.; Garges, S.; Giovanni, M.; McInnes, P.; Wang, L.; Schloss, J.A.; Bonazzi, V.; McEwen, J.E.; Wetterstrand, K.A.; Deal, C.; et al. The NIH Human Microbiome Project. Genome Res. 2009, 19, 2317-2323. [CrossRef] [PubMed] 
81. Kasai, C.; Sugimoto, K.; Moritani, I.; Tanaka, J.; Oya, Y.; Inoue, H.; Tameda, M.; Shiraki, K.; Ito, M.; Takei, Y.; et al. Comparison of the gut microbiota composition between obese and non-obese individuals in a Japanese population, as analyzed by terminal restriction fragment length polymorphism and next-generation sequencing. BMC Gastroenterol. 2015, 15, 100. [CrossRef] [PubMed]

82. Hills, R.D., Jr.; Pontefract, B.A.; Mishcon, H.R.; Black, C.A.; Sutton, S.C.; Theberge, C.R. Gut Microbiome: Profound Implications for Diet and Disease. Nutrients 2019, 11, 1613. [CrossRef]

83. Chakaroun, R.M.; Massier, L.; Kovacs, P. Gut Microbiome, Intestinal Permeability, and Tissue Bacteria in Metabolic Disease: Perpetrators or Bystanders? Nutrients 2020, 12, 1082. [CrossRef] [PubMed]

84. Zheng, D.; Liwinski, T.; Elinav, E. Interaction between microbiota and immunity in health and disease. Cell Res. 2020, 30, 492-506. [CrossRef]

85. Pushalkar, S.; Hundeyin, M.; Daley, D.; Zambirinis, C.P.; Kurz, E.; Mishra, A.; Mohan, N.; Aykut, B.; Usyk, M.; Torres, L.E.; et al. The Pancreatic Cancer Microbiome Promotes Oncogenesis by Induction of Innate and Adaptive Immune Suppression. Cancer Discov. 2018, 8, 403-416. [CrossRef]

86. Kho, Z.Y.; Lal, S.K. The Human Gut Microbiome-A Potential Controller of Wellness and Disease. Front. Microbiol. 2018, 9, 1835. [CrossRef]

87. Sjöberg, V.; Sandström, O.; Hedberg, M.; Hammarström, S.; Hernell, O.; Hammarström, M.-L. Intestinal T-cell responses in celiac disease-Impact of celiac disease associated bacteria. PLoS ONE 2013, 8, e53414. [CrossRef] [PubMed]

88. Ivanov, I.I.; Atarashi, K.; Manel, N.; Brodie, E.L.; Shima, T.; Karaoz, U.; Wei, D.; Goldfarb, K.C.; Santee, C.A.; Lynch, S.V.; et al. Induction of intestinal Th17 cells by segmented filamentous bacteria. Cell 2009, 139, 485-498. [CrossRef]

89. Underhill, D.M.; Iliev, I.D. The mycobiota: Interactions between commensal fungi and the host immune system. Nat. Rev. Immunol. 2014, 14, 405-416. [CrossRef] [PubMed]

90. Su, H.-J.; Chiu, Y.-T.; Chiu, C.-T.; Lin, Y.-C.; Wang, C.-Y.; Hsieh, J.-Y.; Wei, S.-C. Inflammatory bowel disease and its treatment in 2018: Global and Taiwanese status updates. J. Formos. Med. Assoc. 2019, 118, 1083-1092. [CrossRef] [PubMed]

91. Iliev, I.D.; Funari, V.A.; Taylor, K.D.; Nguyen, Q.; Reyes, C.N.; Strom, S.P.; Brown, J.; Becker, C.A.; Fleshner, P.R.; Dubinsky, M.; et al. Interactions between commensal fungi and the C-type lectin receptor Dectin-1 influence colitis. Science 2012, 336, $1314-1317$. [CrossRef] [PubMed]

92. De Sire, R.; Talocco, C.; Petito, V.; Lopetuso, L.R.; Graziani, C.; Gasbarrini, A.; Scaldaferri, F. Microbiota and inflammatory bowel disease: An update. Recenti Progress. Med. 2018, 109, 570-573.

93. Knox, N.C.; Forbes, J.D.; van Domselaar, G.; Bernstein, C.N. The Gut Microbiome as a Target for IBD Treatment: Are We There Yet? Curr. Treat. Options Gastroenterol. 2019, 17, 115-126. [CrossRef] [PubMed]

94. Zuo, T.; Ng, S.C. The Gut Microbiota in the Pathogenesis and Therapeutics of Inflammatory Bowel Disease. Front. Microbiol. 2018, 9, 2247. [CrossRef] [PubMed]

95. Bai, T.; Xia, J.; Jiang, Y.; Cao, H.; Zhao, Y.; Zhang, L.; Wang, H.; Song, J.; Hou, X. Comparison of the Rome IV and Rome III criteria for IBS diagnosis: A cross-sectional survey. J. Gastroenterol. Hepatol. 2017, 32, 1018-1025. [CrossRef]

96. Sundin, J.; Öhman, L.; Simrén, M. Understanding the Gut Microbiota in Inflammatory and Functional Gastrointestinal Diseases. Psychosom. Med. 2017, 79, 857-867. [CrossRef]

97. Brint, E.K.; MacSharry, J.; Fanning, A.; Shanahan, F.; Quigley, E.M. Differential expression of toll-like receptors in patients with irritable bowel syndrome. Am. J. Gastroenterol. 2011, 106, 329-336. [CrossRef] [PubMed]

98. Zu, Z.Y.; Jiang, M.D.; Xu, P.P.; Chen, W.; Ni, Q.Q.; Lu, G.M.; Zhang, L.J. Coronavirus Disease 2019 (COVID-19): A Perspective from China. Radiology 2020, 296, E15-E25. [CrossRef]

99. Bingula, R.; Filaire, M.; Radosevic-Robin, N.; Bey, M.; Berthon, J.-Y.; Bernalier-Donadille, A.; Vasson, M.-P.; Filaire, E. Desired turbulence? Gut-lung axis, immunity, and lung cancer. J. Oncol. 2017, 2017. [CrossRef]

100. Boursi, B.; Mamtani, R.; Haynes, K.; Yang, Y.-X. Recurrent antibiotic exposure may promote cancer formation-Another step in understanding the role of the human microbiota? Eur. J. Cancer 2015, 51, 2655-2664. [CrossRef]

101. Looft, T.; Allen, H.K. Collateral effects of antibiotics on mammalian gut microbiomes. Gut Microbes 2012, 3, 463-467. [CrossRef]

102. Dhar, D.; Mohanty, A. Gut microbiota and Covid-19- possible link and implications. Virus Res. 2020, 285, 198018. [CrossRef]

103. Vergin, F. Antibiotics and probiotics. Hippokrates 1954, 25, 116-119. [PubMed]

104. Food and Agriculture Organization of the United Nations; World Health Organization. Probiotics in Food: Health and Nutritional Properties and Guidelines for Evaluation; World Health Organization: Geneva, Switzerland; Food and Agriculture Organization of the United Nations: Rome, Italy, 2006.

105. Reuter, G. The Lactobacillus and Bifidobacterium microflora of the human intestine: Composition and succession. Curr. Issues Intest. Microbiol. 2001, 2, 43-53.

106. EFSA Panel on Additives and Products or Substances used in Animal Feed (FEEDAP); Rychen, G.; Aquilina, G.; Azimonti, G.; Bampidis, V.; De Lourdes Bastos, M.; Bories, G.; Chesson, A.; Cocconcelli, P.S.; Flachowsky, G.; et al. Guidance on the characterisation of microorganisms used as feed additives or as production organisms. EFSA J. 2018, 16, e05206. [CrossRef]

107. Gaggìa, F.; Mattarelli, P.; Biavati, B. Probiotics and prebiotics in animal feeding for safe food production. Int. J. Food Microbiol. 2010, 141 (Suppl. 1), S15-S28. [CrossRef] 
108. Ustunol, Z. Development and Manufacture of Yogurt and Other Functional Dairy Products (2010), edited by F. Yildiz, CRC Press (Taylor and Francis Group), Boca Raton, Florida, USA. ISBN 978-1-4200-8207-4. Price £127.00. Int. J. Dairy Technol. 2013, 66, 300-301. [CrossRef]

109. Dargahi, N.; Johnson, J.; Donkor, O.; Vasiljevic, T.; Apostolopoulos, V. Immunomodulatory effects of probiotics: Can they be used to treat allergies and autoimmune diseases? Maturitas 2019, 119, 25-38. [CrossRef] [PubMed]

110. Servin, A.L. Antagonistic activities of lactobacilli and bifidobacteria against microbial pathogens. FEMS Microbiol. Rev. 2004, 28, 405-440. [CrossRef] [PubMed]

111. Mack, D.R.; Michail, S.; Wei, S.; McDougall, L.; Hollingsworth, M.A. Probiotics inhibit enteropathogenic E. coli adherence in vitro by inducing intestinal mucin gene expression. Am. J. Physiol. 1999, 276, G941-G950. [CrossRef]

112. Pessi, T.; Sütas, Y.; Hurme, M.; Isolauri, E. Interleukin-10 generation in atopic children following oral Lactobacillus rhamnosus GG. Clin. Exp. Allergy 2000, 30, 1804-1808. [CrossRef]

113. Cebra, J.J. Influences of microbiota on intestinal immune system development. Am. J. Clin. Nutr. 1999, 69, 1046s-1051s. [CrossRef]

114. Kirjavainen, P.V.; Arvola, T.; Salminen, S.J.; Isolauri, E. Aberrant composition of gut microbiota of allergic infants: A target of bifidobacterial therapy at weaning? Gut 2002, 51, 51-55. [CrossRef] [PubMed]

115. Mohan, R.; Koebnick, C.; Schildt, J.; Schmidt, S.; Mueller, M.; Possner, M.; Radke, M.; Blaut, M. Effects of Bifidobacterium lactis Bb12 supplementation on intestinal microbiota of preterm infants: A double-blind, placebo-controlled, randomized study. J. Clin. Microbiol. 2006, 44, 4025-4031. [CrossRef]

116. Yildizdaş, H.Y. Probiyotikler ve Çocuklarda Bağışıklık Sistemi. Klin. Tıp Pediatri Derg. 2016, 8, 5-10.

117. Gill, H.S.; Rutherfurd, K.J.; Prasad, J.; Gopal, P.K. Enhancement of natural and acquired immunity by Lactobacillus rhamnosus (HN001), Lactobacillus acidophilus (HN017) and Bifidobacterium lactis (HN019). Br. J. Nutr. 2000, 83, 167-176. [CrossRef]

118. D'Amico, F.; Baumgart, D.C.; Danese, S.; Peyrin-Biroulet, L. Diarrhea during COVID-19 infection: Pathogenesis, epidemiology, prevention and management. Clin. Gastroenterol. Hepatol. 2020, 18, 1663-1672. [CrossRef] [PubMed]

119. Xiao, A.T.; Tong, Y.X.; Gao, C.; Zhu, L.; Zhang, Y.J.; Zhang, S. Dynamic profile of RT-PCR findings from 301 COVID-19 patients in Wuhan, China: A descriptive study. J. Clin. Virol. 2020, 127, 104346. [CrossRef] [PubMed]

120. Chai, W.; Burwinkel, M.; Wang, Z.; Palissa, C.; Esch, B.; Twardziok, S.; Rieger, J.; Wrede, P.; Schmidt, M.F. Antiviral effects of a probiotic Enterococcus faecium strain against transmissible gastroenteritis coronavirus. Arch. Virol. 2013, 158, 799-807. [CrossRef] [PubMed]

121. Seo, B.J.; Mun, M.R.; Kim, C.-J.; Lee, I.; Kim, H.; Park, Y.-H. Putative probiotic Lactobacillus spp. from porcine gastrointestinal tract inhibit transmissible gastroenteritis coronavirus and enteric bacterial pathogens. Trop. Anim. Health Prod. 2010, 42, 1855-1860.

122. Mahooti, M.; Abdolalipour, E.; Salehzadeh, A.; Mohebbi, S.R.; Gorji, A.; Ghaemi, A. Immunomodulatory and prophylactic effects of Bifidobacterium bifidum probiotic strain on influenza infection in mice. World J. Microbiol. Biotechnol. 2019, 35, 1-9. [CrossRef] [PubMed]

123. Shoaib, A.; Xin, L.; Xin, Y. Oral administration of Lactobacillus acidophilus alleviates exacerbations in Pseudomonas aeruginosa and Staphylococcus aureus pulmonary infections. Pak. J. Pharm. Sci. 2019, 32, 1621-1630.

124. Eguchi, K.; Fujitani, N.; Nakagawa, H.; Miyazaki, T. Prevention of respiratory syncytial virus infection with probiotic lactic acid bacterium Lactobacillus gasseri SBT2055. Sci. Rep. 2019, 9, 1-11. [CrossRef]

125. Fiore, W.; Arioli, S.; Guglielmetti, S. The Neglected Microbial Components of Commercial Probiotic Formulations. Microorganisms 2020, 8, 1177. [CrossRef]

126. Sanders, M.E. Dead Bacteria-Despite Potential for Benefit-Are NOT Probiotics. 2018. Available online: https://isappscience. org/dead-bacteria-not-probiotics / (accessed on 15 May 2021).

127. Seth, S.D.; Maulik, M. Probiotic Foods in Health and Disease, 1st ed.; Nair, G.B., Takeda, Y., Eds.; CRC Press: Boca Raton, FL, USA, 2011; pp. 41-47.

128. Lerner, A.; Shoenfeld, Y.; Matthias, T. Probiotics: If It Does Not Help It Does Not Do Any Harm. Really? Microorganisms 2019, 7, 104. [CrossRef]

129. Bafeta, A.; Koh, M.; Riveros, C.; Ravaud, P. Harms Reporting in Randomized Controlled Trials of Interventions Aimed at Modifying Microbiota: A Systematic Review. Ann. Intern. Med. 2018, 169, 240-247. [CrossRef]

130. Sotoudegan, F.; Daniali, M.; Hassani, S.; Nikfar, S.; Abdollahi, M. Reappraisal of probiotics' safety in human. Food Chem. Toxicol. 2019, 129, 22-29. [CrossRef]

131. Suez, J.; Zmora, N.; Segal, E.; Elinav, E. The pros, cons, and many unknowns of probiotics. Nat. Med. 2019, 25, 716-729. [CrossRef] [PubMed]

132. Ayichew, T.; Belete, A.; Alebachew, T.; Tsehaye, H.; Berhanu, H.; Minwuyelet, A. Bacterial Probiotics their Importances and Limitations: A Review. J. Nutr. Health Sci. 2017, 4. [CrossRef]

133. Evivie, S.E.; Huo, G.-C.; Igene, J.O.; Bian, X. Some current applications, limitations and future perspectives of lactic acid bacteria as probiotics. Food Nutr. Res. 2017, 61, 1318034. [CrossRef]

134. Baugher, J.L.; Klaenhammer, T.R. Invited review: Application of omics tools to understanding probiotic functionality. J. Dairy Sci. 2011, 94, 4753-4765. [CrossRef] [PubMed]

135. Shenderov, B.A. Metabiotics: Novel idea or natural development of probiotic conception. Microb. Ecol. Health Dis. 2013, 24. [CrossRef] 
136. Rao, S.S.C.; Rehman, A.; Yu, S.; Andino, N.M.d. Brain fogginess, gas and bloating: A link between SIBO, probiotics and metabolic acidosis. Clin. Transl. Gastroenterol. 2018, 9, 162. [CrossRef] [PubMed]

137. Suez, J.; Zmora, N.; Zilberman-Schapira, G.; Mor, U.; Dori-Bachash, M.; Bashiardes, S.; Zur, M.; Regev-Lehavi, D.; Ben-Zeev Brik, R.; Federici, S.; et al. Post-Antibiotic Gut Mucosal Microbiome Reconstitution Is Impaired by Probiotics and Improved by Autologous FMT. Cell 2018, 174, 1406-1423.e16. [CrossRef] [PubMed]

138. Collinson, S.; Deans, A.; Padua-Zamora, A.; Gregorio, G.V.; Li, C.; Dans, L.F.; Allen, S.J. Probiotics for treating acute infectious diarrhoea. Cochrane Database Syst. Rev. 2020, 12, Cd003048. [CrossRef] [PubMed]

139. Doron, S.; Snydman, D.R. Risk and safety of probiotics. Clin. Infect. Dis. Off. Publ. Infect. Dis. Soc. Am. 2015, 60 (Suppl. 2), S129-S134. [CrossRef]

140. Camilleri, M. Leaky gut: Mechanisms, measurement and clinical implications in humans. Gut 2019, 68, 1516-1526. [CrossRef] [PubMed]

141. Jacobi, C.A.; Schulz, C.; Malfertheiner, P. Treating critically ill patients with probiotics: Beneficial or dangerous? Gut Pathog. 2011, 3, 2. [CrossRef] [PubMed]

142. Kim, M.J.; Ku, S.; Kim, S.Y.; Lee, H.H.; Jin, H.; Kang, S.; Li, R.; Johnston, T.V.; Park, M.S.; Ji, G.E. Safety Evaluations of Bifidobacterium bifidum BGN4 and Bifidobacterium longum BORI. Int. J. Mol. Sci. 2018, 19, 1422. [CrossRef]

143. Redman, M.G.; Ward, E.J.; Phillips, R.S. The efficacy and safety of probiotics in people with cancer: A systematic review. Ann. Oncol. 2014, 25, 1919-1929. [CrossRef] [PubMed]

144. Wang, Y.H.; Yao, N.; Wei, K.K.; Jiang, L.; Hanif, S.; Wang, Z.X.; Pei, C.X. The efficacy and safety of probiotics for prevention of chemoradiotherapy-induced diarrhea in people with abdominal and pelvic cancer: A systematic review and meta-analysis. Eur. J. Clin. Nutr. 2016, 70, 1246-1253. [CrossRef] [PubMed]

145. Neu, J.; Walker, W.A. Necrotizing enterocolitis. N. Engl. J. Med. 2011, 364, 255-264. [CrossRef]

146. Zbinden, A.; Zbinden, R.; Berger, C.; Arlettaz, R. Case series of Bifidobacterium longum bacteremia in three preterm infants on probiotic therapy. Neonatology 2015, 107, 56-59. [CrossRef]

147. Esaiassen, E.; Cavanagh, P.; Hjerde, E.; Simonsen, G.S.; Støen, R.; Klingenberg, C. Bifidobacterium longum Subspecies infantis Bacteremia in 3 Extremely Preterm Infants Receiving Probiotics. Emerg. Infect. Dis. 2016, 22, 1664-1666. [CrossRef]

148. Van den Akker, C.H.P.; van Goudoever, J.B.; Shamir, R.; Domellöf, M.; Embleton, N.D.; Hojsak, I.; Lapillonne, A.; Mihatsch, W.A.; Berni Canani, R.; Bronsky, J.; et al. Probiotics and Preterm Infants: A Position Paper by the European Society for Paediatric Gastroenterology Hepatology and Nutrition Committee on Nutrition and the European Society for Paediatric Gastroenterology Hepatology and Nutrition Working Group for Probiotics and Prebiotics. J. Pediatr. Gastroenterol. Nutr. 2020, 70, 664-680. [CrossRef]

149. De Almada, C.N.; De Almada, C.N.; de Souza Sant'Ana, A. Probiotics and Prebiotics in Animal Health and Food Safety. In Araprobiotics as Potential Agents for Improving Animal Health; Di Gioia, D., Biavati, B., Eds.; Springer: Cham, Switzerland, 2018; pp. 247-268.

150. Martín, R.; Langella, P. Emerging Health Concepts in the Probiotics Field: Streamlining the Definitions. Front. Microbiol. 2019, 10, 1047. [CrossRef]

151. Sharma, M.; Shukla, G. Metabiotics: One Step ahead of Probiotics; an Insight into Mechanisms Involved in Anticancerous Effect in Colorectal Cancer. Front. Microbiol. 2016, 7, 1940. [CrossRef] [PubMed]

152. Zendeboodi, F.; Khorshidian, N.; Mortazavian, A.M.; da Cruz, A.G. Probiotic: Conceptualization from a new approach. Curr. Opin. Food Sci. 2020, 32, 103-123. [CrossRef]

153. Salminen, S.; Collado, M.C.; Endo, A.; Hill, C.; Lebeer, S.; Quigley, E.M.M.; Sanders, M.E.; Shamir, R.; Swann, J.R.; Szajewska, H.; et al. The International Scientific Association of Probiotics and Prebiotics (ISAPP) consensus statement on the definition and scope of postbiotics. Nat. Rev. Gastroenterol. Hepatol. 2021. [CrossRef]

154. Tsilingiri, K.; Barbosa, T.; Penna, G.; Caprioli, F.; Sonzogni, A.; Viale, G.; Rescigno, M. Probiotic and postbiotic activity in health and disease: Comparison on a novel polarised ex-vivo organ culture model. Gut 2012, 61, 1007-1015. [CrossRef] [PubMed]

155. Kleerebezem, M.; Hols, P.; Bernard, E.; Rolain, T.; Zhou, M.; Siezen, R.J.; Bron, P.A. The extracellular biology of the lactobacilli. FEMS Microbiol. Rev. 2010, 34, 199-230. [CrossRef] [PubMed]

156. De Almada, C.N.; Almada, C.N.; Martinez, R.C.R.; Sant'Ana, A.S. Paraprobiotics: Evidences on their ability to modify biological responses, inactivation methods and perspectives on their application in foods. Trends Food Sci. Technol. 2016, 58, 96-114. [CrossRef]

157. Piqué, N.; Berlanga, M.; Miñana-Galbis, D. Health Benefits of Heat-Killed (Tyndallized) Probiotics: An Overview. Int. J. Mol. Sci. 2019, 20, 2534. [CrossRef] [PubMed]

158. Teame, T.; Wang, A.; Xie, M.; Zhang, Z.; Yang, Y.; Ding, Q.; Gao, C.; Olsen, R.E.; Ran, C.; Zhou, Z. Paraprobiotics and Postbiotics of Probiotic Lactobacilli, Their Positive Effects on the Host and Action Mechanisms: A Review. Front. Nutr. 2020, 7. [CrossRef] [PubMed]

159. Ou, C.C.; Lin, S.L.; Tsai, J.J.; Lin, M.Y. Heat-killed lactic acid bacteria enhance immunomodulatory potential by skewing the immune response toward Th1 polarization. J. Food Sci. 2011, 76, M260-M267. [CrossRef] [PubMed]

160. Wu, Z.; Pan, D.; Guo, Y.; Sun, Y.; Zeng, X. Peptidoglycan diversity and anti-inflammatory capacity in Lactobacillus strains. Carbohydr. Polym. 2015, 128, 130-137. [CrossRef] 
161. Servi, B.; Ranzini, F. Protective efficacy of antidiarrheal agents in a permeability model of Escherichia coli-infected CacoGoblet ${ }^{\circledR}$ cells. Future Microbiol. 2017, 12, 1449-1455. [CrossRef]

162. Marcial, G.; Villena, J.; Faller, G.; Hensel, A.; de Valdéz, G.F. Exopolysaccharide-producing Streptococcus thermophilus CRL1190 reduces the inflammatory response caused by Helicobacter pylori. Benef. Microbes 2017, 8, 451-461. [CrossRef]

163. Generoso, S.V.; Viana, M.L.; Santos, R.G.; Arantes, R.M.E.; Martins, F.S.; Nicoli, J.R.; Machado, J.A.N.; Correia, M.I.T.D.; Cardoso V.N. Protection against increased intestinal permeability and bacterial translocation induced by intestinal obstruction in mice treated with viable and heat-killed Saccharomyces boulardii. Eur. J. Nutr. 2011, 50, 261-269. [CrossRef]

164. Zagato, E.; Mileti, E.; Massimiliano, L.; Fasano, F.; Budelli, A.; Penna, G.; Rescigno, M. Lactobacillus paracasei CBA L74 metabolic products and fermented milk for infant formula have anti-inflammatory activity on dendritic cells in vitro and protective effects against colitis and an enteric pathogen in vivo. PLoS ONE 2014, 9, e87615. [CrossRef]

165. Gao, J.; Li, Y.; Wan, Y.; Hu, T.; Liu, L.; Yang, S.; Gong, Z.; Zeng, Q.; Wei, Y.; Yang, W.; et al. A Novel Postbiotic from Lactobacillus rhamnosus GG With a Beneficial Effect on Intestinal Barrier Function. Front. Microbiol. 2019, 10. [CrossRef] [PubMed]

166. Wang, Y.; Xie, J.; Wang, N.; Li, Y.; Sun, X.; Zhang, Y.; Zhang, H. Lactobacillus casei Zhang modulate cytokine and toll-like receptor expression and beneficially regulate poly I:C-induced immune responses in RAW264.7 macrophages. Microbiol. Immunol. 2013, 57, 54-62. [CrossRef]

167. Kamilya, D.; Baruah, A.; Sangma, T.; Chowdhury, S.; Pal, P. Inactivated Probiotic Bacteria Stimulate Cellular Immune Responses of Catla, Catla catla (Hamilton) In Vitro. Probiotics Antimicrob. Proteins 2015, 7, 101-106. [CrossRef] [PubMed]

168. Chen, C.Y.; Tsen, H.Y.; Lin, C.L.; Lin, C.K.; Chuang, L.T.; Chen, C.S.; Chiang, Y.C. Enhancement of the immune response against Salmonella infection of mice by heat-killed multispecies combinations of lactic acid bacteria. J. Med. Microbiol. 2013, 62, 1657-1664. [CrossRef] [PubMed]

169. Miyazawa, K.; He, F.; Kawase, M.; Kubota, A.; Yoda, K.; Hiramatsu, M. Enhancement of immunoregulatory effects of Lactobacillus gasseri TMC0356 by heat treatment and culture medium. Lett. Appl. Microbiol. 2011, 53, 210-216. [CrossRef]

170. Chuang, L.; Wu, K.-G.; Pai, C.; Hsieh, P.-S.; Tsai, J.-J.; Yen, J.-H.; Lin, M.-Y. Heat-Killed Cells of Lactobacilli Skew the Immune Response Toward T Helper 1 Polarization in Mouse Splenocytes and Dendritic Cell-Treated T Cells. J. Agric. Food Chem. 2007, 55, 11080-11086. [CrossRef] [PubMed]

171. Deshpande, G.; Athalye-Jape, G.; Patole, S. Para-probiotics for Preterm Neonates-The Next Frontier. Nutrients $2018,10,871$. [CrossRef]

172. Zawistowska-Rojek, A.; Tyski, S. Are Probiotic Really Safe for Humans? Pol. J. Microbiol. 2018, 67, 251-258. [CrossRef] [PubMed]

173. Taverniti, V.; Guglielmetti, S. The immunomodulatory properties of probiotic microorganisms beyond their viability (ghost probiotics: Proposal of paraprobiotic concept). Genes Nutr. 2011, 6, 261-274. [CrossRef]

174. Aguilar-Toalá, J.E.; García-Varela, R.; García, H.; Mata-Haro, V.; González-Córdova, A.; Vallejo-Cordoba, B.; Hernández-Mendoza, A. Postbiotics: An evolving term within the functional foods field. Trends Food Sci. Technol. 2018, 75, 105-114. [CrossRef]

175. Iravani, S.; Korbekandi, H.; Mirmohammadi, S.V. Technology and potential applications of probiotic encapsulation in fermented milk products. J. Food Sci. Technol. 2015, 52, 4679-4696. [CrossRef] [PubMed]

176. Tripathi, M.K. Probiotic functional foods: Survival of probiotics during processing and storage. J. Funct. Foods 2014, 9, $225-241$. [CrossRef]

177. Perricone, M.; Bevilacqua, A.; Altieri, C.; Sinigaglia, M.; Corbo, M.R. Challenges for the Production of Probiotic Fruit Juices. Beverages 2015, 1, 95-103. [CrossRef]

178. Venema, K. Beneficial microbes. Foreword. Benef. Microbes 2012, 3, 1-2. [CrossRef]

179. Barros, C.P.; Guimarães, J.T.; Esmerino, E.A.; Duarte, M.C.K.H.; Silva, M.C.; Silva, R.; Ferreira, B.M.; Sant'Ana, A.S.; Freitas, M.Q.; Cruz, A.G. Paraprobiotics and postbiotics: Concepts and potential applications in dairy products. Curr. Opin. Food Sci. 2020, 32, 1-8. [CrossRef]

180. Ali, K.; Mehmood, M.H.; Iqbal, M.A.; Masud, T.; Qazalbash, M.; Saleem, S.; Ahmed, S.; Tariq, M.R.; Safdar, W.; Nasir, M.A.; et al. Isolation and characterization of exopolysaccharide-producing strains of Lactobacillus bulgaricus from curd. Food Sci. Nutr. 2019, 7, 1207-1213. [CrossRef]

181. Slim, S.; Elleuch, L.; Ben Salah, R.; Najah, S.; Chakchouk-Mtibaa, A.; Sellem, I.; Besbes, S.; Mellouli, L. Efficient role of BacTN635 on the safety properties, sensory attributes, and texture profile of raw minced meat beef and chicken breast. Food Addit. Contam. Part A 2013. [CrossRef]

182. Da Costa, R.J.; Voloski, F.L.S.; Mondadori, R.G.; Duval, E.H.; Fiorentini, Â.M. Preservation of Meat Products with Bacteriocins Produced by Lactic Acid Bacteria Isolated from Meat. J. Food Qual. 2019, 2019, 4726510. [CrossRef]

183. Tenea, G.; Barrigas, A. The efficacy of bacteriocin-containing cell-free supernatant from Lactobacillus plantarum Cys5-4 to control pathogenic bacteria growth in artisanal beverages. Int. Food Res. J. 2018, 25, 2131-2137.

184. Shehata, M.G.; Badr, A.N.; El Sohaimy, S.A.; Asker, D.; Awad, T.S. Characterization of antifungal metabolites produced by novel lactic acid bacterium and their potential application as food biopreservatives. Ann. Agric. Sci. 2019, 64, 71-78. [CrossRef]

185. Murata, M.; Kondo, J.; Iwabuchi, N.; Takahashi, S.; Yamauchi, K.; Abe, F.; Miura, K. Effects of paraprobiotic Lactobacillus paracasei MCC1849 supplementation on symptoms of the common cold and mood states in healthy adults. Benef. Microbes 2018, 9, 855-864. [CrossRef]

186. Jensen, G.S.; Cash, H.A.; Farmer, S.; Keller, D. Inactivated probiotic Bacillus coagulans GBI-30 induces complex immune activating, anti-inflammatory, and regenerative markers in vitro. J. Inflamm. Res. 2017, 10, 107-117. [CrossRef] [PubMed] 
187. Martinelli, M.; Ummarino, D.; Giugliano, F.P.; Sciorio, E.; Tortora, C.; Bruzzese, D.; de Giovanni, D.; Rutigliano, I.; Valenti, S.; Romano, C.; et al. Efficacy of a standardized extract of Matricariae chamomilla L., Melissa officinalis L. and tyndallized Lactobacillus acidophilus (HA122) in infantile colic: An open randomized controlled trial. Neurogastroenterol. Motil. 2017, 29. [CrossRef] [PubMed]

188. Liévin-Le Moal, V. A gastrointestinal anti-infectious biotherapeutic agent: The heat-treated Lactobacillus LB. Ther. Adv. Gastroenterol. 2016, 9, 57-75. [CrossRef]

189. Sichel, L.; Timoshok, N.; Pidgorskyy, V.; Spivak, N. Study of interferonogenous activity of the new probiotic formulation Del-Immune $\mathrm{V}^{\circledR}$. J. Probiotics Health 2013, 1. [CrossRef]

190. Omarov, T.R.; Omarova, L.A.; Omarova, V.A.; Sarsenova, S.V. The chronic gastritis, the dysbacteriosis and the use of Hylak forte at the treatment. Wiad Lek. 2014, 67, 365-367. 